\title{
Independent Director, Executives Compensation and Corporate Performance-Correcting Self-Selection Bias by Matching Methods
}

\author{
Yuan Chang ${ }^{1,2} \&$ Pang-Tien Lieu ${ }^{1}$ \\ ${ }^{1}$ Department of Business Administration, National Taiwan University of Science and Technology, Taiwan \\ (R.O.C) \\ ${ }^{2}$ Department of Finance, National Changhua University of Education, Taiwan (R.O.C) \\ Correspondence: Yuan Chang, Department of Finance, National Changhua University of Education, No.2, \\ Shi-Da Road, Changhua City, Taiwan (R.O.C). Tel: 886-47-232-105-7350. E-mail: ychang@cc.ncue.edu.tw
}

Received: June 2, 2016

Accepted: June 18, 2016

Online Published: July 25, 2016

doi:10.5539/ijef.v8n8p156

URL: http://dx.doi.org/10.5539/ijef.v8n8p156

\begin{abstract}
Based on data of listed companies on Taiwan Stock Exchange (TWSE) through 2001 2011, this paper examines whether board independence has effects on executive compensation and corporate performance. Existing studies lacked of considering self-selection of board independence in evaluating the effects of board independence on economic consequence. This may incur estimation bias because systematic factors determining firm's introducing independent director also have influences on economic consequence. While Heckman (1979)'s two-step estimation addressed selection duo to unobservables, this paper employs propensity score matching (PSM) from Rosenbaum and Rubin $(1983,1985 a, b)$ to address sample selection duo to observables, and forms two groups of samples, namely, firms with independent director and firms without independent director but share similar characteristics with the former. Empirical evidence from regression estimation shows divergent outcomes under before-matching versus after-matching samples. Before matching, greater degree of board independence is associated with higher profitability and higher level of total and average executive compensation. After matching, outperformance as well as overpay on executive compensation of firm with greater board independence is vanished. After controlling selection bias duo to observables versus unobservables, our evidence concludes that greater board independence is uncorrelated with greater corporate performance and executive compensation overpay.
\end{abstract}

Keywords: board independence, executives compensation, self-selection bias, propensity score matching

\section{Introduction}

During recent two decades, successive corporate scandals such as Enron, Tyco, and World.Com occurred, highlighted serious shortcomings of oversight by board of directors and external auditor. In recent Asia, corporate scandals are also frequently occurred. Family ownership and corporate groups lead to excessive concentration of equity holdings, insider trading, related-party transactions and earnings false. While conventional wisdom regarded board of director as an important mechanism of internal corporate governance, board of director still also criticized for maintaining familiar relation with the management or CEO that may interfere with the duty of managerial monitoring (Jensen, 1993). Thus, increasing independent director representation on the corporate board to improve board oversight is an innocent prescription.

In 2002, the U.S. Congress passed the Sarbanes-Oxley Act (SOX), and one important component of the SOX Act is to require independence of board's auditing committee. Meanwhile, the New York Stock Exchange and Nasdaq also improved listing rule to increase required percentage of independent director on corporate board and board's committees (for example, auditing, nominating and compensation committee). The Taiwan Stock Exchange (TWSE) amended "Guidelines for the Review and Listing Rules of Securities on TWSE" in February 2002. The new listing rule requires newly-listed companies must employ at least two independent directors and one independent supervisors to contribute their independent and professional function. Firms with larger equity must also delegate independent director (Note 1). According to $\mathrm{Su}$ (2010), the ratio of independent director rose slowly (35.2\% in 2005 to $37.8 \%$ in 2009) for listed companies on TWSE, implies that introducing independent director on the board may not be very well-recognized by all companies. 
If a board has independent director, on the surface, crony and economic ties to the management is reduced, thus they are believed to be more willing to challenge CEO or the management than other (gray/inside) director. Fama (1980) argued that independent director performs better on managerial monitoring than gray/inside director because the former has greater incentives to maintain existing reputation in the market for director. Weisbach (1988), Hermalin and Weisbach (1991, 1998), Raheja (2005), Harris and Raviv (2006) and Adams and Ferreira $(2007,2008)$ indicated monitoring and advising function of director. Monitoring function requires director guarding against managerial harmful behavior for firm such as shirking or fraud. Advising function involves helping the management to form good management decisions. Reputation and professional of independent director enhance functioning of managerial monitoring and advising, thus the board efficiency, quality of managerial decision and other economic outcomes are likely to be better. Firm with independent director tends to have higher ability and capability than others. Firm with independent director tends to have higher quality managerial decision and thus increase competitive advantage and profitability and decreases risk of company.

On the contrary, Jensen (1993) indicated that because independent director faces limitation in accessing firm specific information, the ability of effective monitoring is weakened. Masulis and Mobbs (2012) found that inside director has better firm information than outside director. Outside directorship at unaffiliated firm by inside director is more beneficiary to shareholders. Harris and Raviv (2008) pointed out that because the shareholding of independent director is relatively small, they lack of strong financial incentive to carefully monitor the management. Harris and Raviv (2008) also indicated that increasing the number of independent director aggravates free-rider problem among independent director. Hermalin and Weisbach (2003) indicated that independent director tends to be obedient to increase the likelihood of retaining board seat and receiving additional board appointment. To sum up, lack of relevant information and financial incentive, free-rider problem and obedience may offset the reputational and advising benefit by independent director.

Empirically, Forker (1992) found that the ratio of independent director enhances the quality and disclosure of financial information and reduces the retention of information by interesting party. Brickley, Coles and Terry (1994) found that appointing independent director has positive effect on operating performance. Elliot and Jacobson (1994), Chen and Jaggi (2000) showed that higher percentage of independent director and director having professional background enhances information disclosure and improves performance. Core, Holthausen and Larcker (1999) found that the relationship between independent director ratio and CEO pay is significantly negative, supports the view that board independence enhances corporate governance. Cotter, Anil Shivdasani and Zenner (1997) found that in M\&A activities, target firm with independent director tends to obtain a higher purchase price. Klein (2002) found that firm with higher outside director ratio tends to have less abnormal accruals. Peasnell, Pope, and Young (2005) found that greater number of independent director is related to lower degree of earnings management. Rosenstein and Wyatt (1997) found that company's share price increases significantly following the appointment of independent director. Recent studies could be referred to Fuzi and Julizaerma (2016), Leung, Richardson and Jaggi (2014) and Wang (2014).

However, Bhagat and Black (2002) found that the relationship between board independence and firm performance is significantly negative. Fich and Shivdasani (2006) found that when independent director is busy, monitoring/advising function and board efficiency becomes lower, and the higher the proportion of busy independent director, the lower the corporate performance. Wintoki (2007) and Duchin, Matsusaka and Ozbas (2010) found that when firm's information is difficult to obtain and information disclosure is incomplete, increasing independent director leads to deteriorated performance.

Hermalin and Weisbach (1988) firstly indicated the "endogeneity" of board independence, for example, the board structure often switches when firm changes CEO or confronts poor operation (Note 2). The endogeneity of board independence means that firm with some specific characteristics tends to introduce independent director, and firm without such characteristics tends to have lower degree of board independence. The endogeneity bias occurs because determinants for board independence might also have influences on firm's economic outcome. Specifically, while samples "self-select" to be firm with higher board independence versus firm with lower board independence, difference in economic outcome between firm with higher board independence and lower board independence could be explained by either factors triggering self-selection or marginal impact of board independence on economic outcome. Estimated coefficient of board independence on economic outcome is mixed up with above two influences and is biased in capturing causal effect of board independence on economic outcome (Note 3).

Tucker (2011) made a clarification on some terms of econometric terminology such as "endogeneity", "selection bias", "selection on observables" and "selection on unobservables". "Selection bias" potentially occurs as 
corporate decisions (e.g. board independence) are non-random and the outcomes of choices not made are never observable. Selection bias due to "selection on observables" arises from sample differences that researchers can observe but fail to control. Selection bias due to "selection on unobservables" arises from the unobservable and thus uncontrolled sample differences that affect corporate decisions and economic consequences (Note 4). It is crucial for researchers to account for the observable and unobservable differences between a selected control firm and the ideal control firm in evaluating treatment effects (effect of board independence on economic outcomes). Absent controls for these differences, selection bias, which is one form of endogeneity problem, can lead to inappropriate inference about treatment effect. "Endogeneity" means that the covariates are correlated with the error term (Wooldridge, 2002) and thus endogeneity exists in cases of selection on observables and selection on unobservables as well as in other omitted-correlated-variable situations (Tucker, 2011).

Addressing selection bias due to unobservables follows Heckman (1979)'s two-stage estimation such that treatment choice (board independence) is binary and the policy outcomes depend on a linear combination of observable and unobservable factors. More specifically, this approach estimates the choice model in the first stage, and then restricts unobservables to multivariate normal distributions to derive bias correction term (Inverse Mills Ratio), and then adds this bias correction term in the second-stage regression (Tucker, 2011). However, Because Inverse Mills Ratio is derived from truncated binormal distributions, it is only appropriate if the first-stage choice decision is modeled in probit, and the second stage outcome is modeled in a linear regression, and if the unobservables in the two stages are bi-normally distributed. The success of mitigating selection bias depends on model specification and variable measurement and estimation result is very sensitive to model specifications of two stages (Tucker, 2007).

Addressing selection bias due to observables by matching a participant (board with independence) with a non-participant (board without independence) with similar observable characteristics (such as firm size, sales growth and industry) is also well-applied in economics, finance and accounting research (Note 5). Despite as the number of matching dimensions grows indeed incurs difficulty on matching, aggregating all matching covariates into one score by a likelihood function overcome this multi-dimensionality matching problem. Matching by an aggregate score of treatment propensity, Propensity Score Matching (PSM), is proposed by Rosenbaum and Rubin (1983, 1985a,b) and involves two steps: the first step is to estimate the probability function of being treated for all samples by observable characteristic variables, and then obtain estimated probability (propensity score) of being treated for each samples (treated and untreated). Second, for each treated sample (for examples, firm with board independence), samples in the untreated (firm without board independence) are selected as matched samples according to the closeness of the propensity score.

The purpose of this study is to investigate the effect of board independence on executive compensation and corporate performance. This is particularly important because recent studies have revealed that the quality of managerial decisions can significantly affect the prosperity of the companies and can help the firms to become more competitive in the markets (Riasi, 2015). To study the effect of board independence, the best research design is to compare the outcome of independent board versus not independent board for a given firm at given point of time, however, for a given firm, we can observe the board condition with independence but not the board condition without independence at the same time. To overcome this problem, the second best research design is to select a control firm (firm without board independence) that is as identical as possible to the treated (firm without board independence), except for the control did not join the treatment. As mentioned above, selection bias occurs when the researcher fail to control for observable as well as unobservable differences between treated and control. The main purpose of this paper is to mitigate selection bias when evaluating the effect of board independence on executive compensation and corporate performance. The sample is listed firms on Taiwan Stock Exchange (TWSE) and the data is ranged from 2001 to 2011.

While Heckman's two stage estimation is well-documented and familiar in the existing studies, the focus of this paper is on introduction of matching methods (Rubin, 1973, 1977) and Propensity Score Matching (Rosenbaum \& Rubin, 1983; 1985a,b). Four matching algorithms, Nearest, Caliper, Mahala and Mahala Caliper are used to match the observable financial characteristics of two groups firms (with/without independent director) to correct for selection bias due to selection on observables (Note 6). The concept behind these matching algorithms is to find counterfactual samples for treated samples, namely, samples sharing similar financial characteristics (likelihood to be treated) with the treated (firm with board independence) but without being treated. By analyzing after-matching samples, harassment by selection bias of effect of board independence on executive compensation and corporate performance could be mitigated.

Our finding generally shows that, without matching, even considering several control factors in regression, firm with board independence still has higher total and average executive compensation and better corporate 
performance. After matching, evidence of outperformance of firms with greater degree of board independence is almost vanished, so does higher average amount of executive compensation. Heckman's (1979) two-stage estimation obtains similar results.

The paper is organized as followed. Next section briefly introduces basic concept and implementation of matching and propensity score matching. Section 3 describes variables, data econometric model. Section 4 reports the empirical result and the final section is conclusion.

\section{Matching Theory and Propensity Score Matching}

\subsection{Basic Concept of Matching Theory}

Matching theory is developed to address the sample selection bias due to sample selection on observables. Following Dehejia and Wahba (2002), let $Y_{i 1}$ denote the value of outcome variable (executive compensation or corporate performance) for firm $i$ when it is subject to treatment (with board independence), $Y_{i 0}$ is the value of outcome of firm $i$ when it is exposed to the control (without board independence). The outcome difference between $Y_{i 1}$ and $Y_{i 0}$ is regarded as treatment (or experimental) effect of board independence on outcome variable. Specifically, $\tau_{i}=Y_{i 1}-Y_{i 0}$ is treatment effect of board independence for firm $i$. Under numerous firm $i$, expected treatment effect over the treated population is (we omit subscript $i$ below for simplicity):

$$
\left.\tau\right|_{T=1} \equiv E(\tau \mid T=1)=E\left(Y_{1}-Y_{0} \mid T=1\right)=E\left(Y_{1} \mid T=1\right)-E\left(Y_{0} \mid T=1\right)
$$

where $\left.\tau\right|_{T=1}$ is average (expected) treatment effect on the treated (ATET), and $T=1$ if the sample is subject to treatment and $T=0$ if the sample exposed to the control. As mentioned in previous section, the basic problem in identifying ATET is that we can observe $Y_{i 1}$ but not $Y_{i 0}$ when firm $i$ is treated $(T=1)$ at a given point of time, so we can estimate $E\left(Y_{1} \mid T=1\right)$ but not $E\left(Y_{0} \mid T=1\right)$. Nevertheless, researcher can still observe $Y_{i 0}$ as long as firm $i$ is exposed to the control $(T=0)$. While $E\left(Y_{0} \mid T=0\right)$ can be estimated, use $E\left(Y_{0} \mid T=0\right)$ to replace $E\left(Y_{0} \mid T=1\right)$ is the second best, thus $\left.\tau\right|_{T=1}$ is proxy by:

$$
\tau^{d} \equiv E\left(Y_{1} \mid T=1\right)-E\left(Y_{0} \mid T=0\right)
$$

If the treated and control groups do not systematically different except for one is treated and the other is untreated, then they are regarded as drawn from same population, that's $Y_{1}, Y_{0} \perp T$, where $\perp$ symbolizes for statistical independence. Under this situation, $E\left(Y_{0} \mid T=1\right)=E\left(Y_{0} \mid T=0\right)$, in terminology of Rubin (1973), Ignorability of Treatment Condition (ITC) is satisfied, and thus $\tau^{d}=\left.\tau\right|_{T=1}$. Otherwise, treated and control groups are considered to be drawn from different population, and $\tau^{d}$ is a biased proxy estimator for $\left.\tau\right|_{T=1}$, the difference from $\tau^{d}$ to $\left.\tau\right|_{T=1}$ is the selection bias:

$$
\begin{aligned}
\tau^{d}-\left.\tau\right|_{T=1} & =\left[E\left(Y_{1} \mid T=1\right)-E\left(Y_{0} \mid T=0\right)\right]-\left[E\left(Y_{1} \mid T=1\right)-E\left(Y_{0} \mid T=1\right)\right] \\
& =E\left(Y_{0} \mid T=1\right)-E\left(Y_{0} \mid T=0\right)
\end{aligned}
$$

Practically, if we can choose a control firm from untreated group based on similar observable characteristics such as the same industry and has the closest firm size to the treated firm, $\tau^{d}$ produces the best estimate of ATET (Rosenbaum \& Rubin, 1983; Zhao, 2004).

\subsection{Dimension Reduction through Propensity Score}

When the number of observable characteristics increases, the chance of finding exact control matching for each treated sample is decreasing. In other words, it is more difficult to find a control having exactly same observable characteristics as a given treated sample. Rosenbaum and Rubin (1983, 1985a,b) suggested to use the likelihood to be treated, propensity score, the conditional probability of being treated given a set of characteristic covariates, to reduce the dimension of matching.

Let $P(X)$ be the probability of treated sample,

$$
\begin{gathered}
P(X)=P(T=1 \mid X)=E(T=1 \mid X) \\
Y_{i}, Y_{i} \perp T\left|X \quad \Rightarrow Y_{1}, Y_{0} \perp T\right| P(X) \\
\left.\tau\right|_{\mathrm{T}=1}=E_{P(X)}\left[\left.\tau^{d}\right|_{T=1, P(X)}\right]
\end{gathered}
$$


The ITC (Rubin, 1973) extends to using of propensity scores. Selection bias is mitigated as well as dimensionality of matching (Note 7). However, using PSM to draw statistical inference is restricted to firms whose observable characteristics can be matched in both treated and control samples.

\subsection{Matching Algorithm}

Given observable characteristics $X$ and propensity scores $P(X)$ for treated (firm with board independence) and control samples (firm without board independence), a specific sample of treated firm is paired with one or more control samples by following matching criterions.

Define sample $i$ is subject to treatment and sample $j$ is exposed to the control, and propensity score of sample $i$ and $j$ are $P_{i}$ and $P_{j}$, respectively. Nearest-Neighbor Matching (Nearest hereafter), matches each treated sample to one control sample such that two samples have smallest difference in propensity score,

$$
\mathrm{C}\left(P_{i}\right)=\min _{j}\left|P_{i}-P_{j}\right|
$$

where $\mathrm{C}\left(P_{i}\right)$ is a set of control sample which the propensity score is the closest with treated sample $i$.

Second, Caliper Matching (Caliper hereafter), matches each treated sample to control sample such that propensity score difference is within a pre-specified number. In other words, as long as $\left|P_{i}-P_{j}\right|<\eta$, sample $j$ is contained in the $\mathrm{C}\left(P_{i}\right)$ set. While the number of control samples in $\mathrm{C}\left(P_{i}\right)$ is arbitrary under Caliper Matching (Note 8 ), there is only one sample in the $\mathrm{C}\left(P_{i}\right)$ under Nearest-Neighbor Matching.

Third, the Mahalanobis Metric Matching (Mahala hereafter). Based on observable characteristics, Mahalanobis Distance (MD) computes an single measurement of distance between treated $i$ and control $j$ without using of propensity score yet still solve multi-dimensionality problem in matching. Mahalanobis Distance (MD) is calculated as:

$$
d(i, j)=(u-v)^{T} C^{-1}(u-v)
$$

where $u$ and $v$ are vectors of observable characteristics of treated sample $i$ and control sample $j$, respectively. C is variance-covariance matrix of observable characteristics. While the MDs for each pair of treated $i$ and control $j$ are obtained, match each treated sample to a control sample such that their MD is smallest.

Fourth, Mahalanobis Metric Matching with Caliper (Mahala Caliper hereafter) matches each treated sample to control samples with MDs of each other are within a pre-specified number. Specifically, as long as $d(i, j)<\eta$, control $j$ is matched for treated $i$.

\subsection{Verification of Matching Effectiveness}

After matching, we have original treated samples and matched-control samples. How sure are we about observable characteristics are not different between treated samples and matched-control samples? We can verify the effectiveness of matching by examining the null hypothesis of $H_{0}:\left(\bar{X}_{i}-\bar{X}_{j}\right)=0$, where $\bar{X}_{i}$ and $\bar{X}_{j}$ are sample means of a given characteristic variable of treated sample $i$ and control sample $j$, respectively. Matching is effective if the null is not rejected.

Second, we can compute the following,

$$
\frac{\left(\bar{X}_{i B}-\bar{X}_{j B}\right)-\left(\bar{X}_{i A}-\bar{X}_{j A}\right)}{\left(\bar{X}_{i B}-\bar{X}_{j B}\right)} \times 100
$$

where $\bar{X}_{i B}$ and $\bar{X}_{j B}$ are the means of observable characteristics of treated and control samples before matching, respectively. $\bar{X}_{i A}$ and $\bar{X}_{j A}$ are the means of observable characteristics of treated and control samples after matching, respectively. Greater percentage means that the degree of mean difference reduction in a given observable characteristics is larger through matching and thus the matching effectiveness is higher.

\section{Variables and Econometric Model}

\subsection{Board Independence}

The Taiwan Stock Exchange (TWSE) amended the "Guidelines for the Review and Listing Rules of Securities on TWSE" in February 2002. The new listing rule requires listed company on TWSE set at least two independent directors and one independent supervisor to exert independent monitoring and professional advising function. Since January 1, 2007, according to the Article 14 of the "Securities and Exchange Act", financial firms and firms with paid-in capital up to 50 billion NTD (or above) must set at least two independent directors and 
independent director ratio (number of independent director divided by total number of director) cannot be less than $20 \%$. In 2011, listed-firm on TWSE with paid-in capital up to 10 billion NTD must set at least two independent directors. In 2014, all listed companies are required to set at least two independent directors, and similarly, independent director ratio cannot be less than $20 \%$.

Our research period covers 2001 to 2011. During this period, some firms are newly listed on TWSE after 2002, some firms are forced to set independent director because of either paid-in capital reaches setting requirement or be financial firms. To rule out that firm's introducing independent director is forced by government regulation, samples of firm that are listed on TWSW after February 2002, samples of firms that are forced to set independent director and financial firms are all deleted from our samples.

To measure board independence, three measures are employed, first, a dummy variable to proxy board independence, $I D \_d$, where the firm has at least one independent director, $I D \_d$ is equal to 1 , and 0 otherwise. Second, the total number of independent director, $I D \_n u m$. Third, independent director ratio, $I D \_r$, the number of independent director divided by total number of director. $I D \_d$ equal to 1 , higher $I D \_n u m$ and $I D \_r$ represent that firm has greater degree of board independence. The data of the number of independent director and total number of director come from the Taiwan Economic Journal (TEJ), yearly ranged from 2001 to 2011.

\subsection{Self-Selection Factors and Propensity Score Function}

To correct for selection bias due to selection on observables, recall that several factors act as determinants of board independence. Chen and Lin (2011) have indicated that firm's ownership structure and financial characteristics have influence on firm's decision on introducing independent director (other than regulated by government rules). First, outside block shareholder tends to have higher capability and incentive on monitoring the management to enhance corporate performance and reduce executive overpay (Oviatt, 1988; Agrawal \& Mandelker, 1990). Jensen (1993) proposed the alignment hypothesis that when outside block shareholding is high, their personal interest and risk are more linked with firm's performance, thus they have higher incentive to monitor the management. Because one of main purpose independent director is managerial monitoring (Fama and Jensen, 1983), establishment of alignment hypothesis implies that firm's demand on independent director (to monitoring the management) increases as outside block shareholding (Outside) increases. Alternatively, Gordon and Pound (1993) proposed the enchantment hypothesis such that outside block shareholders have their own private interest and are reluctant to be monitored by independent director. Establishment of enchantment hypothesis implies that firm's demand on independent director decreases as outside block shareholding increases.

Second, while institutional investor tends to have greater professional knowledge and lower cost of monitoring, firm with higher institutional investor's shareholding (Insthold) tends to have more effective managerial oversight (Pound, 1988; McConnell \& Servaes, 1990). Similarly, establishment of alignment hypothesis (Jensen, 1993) implies that firm's demand on independent director (to monitoring the management) increases as institutional investor shareholding (Insthold) increases. Alternatively, establishment of enchantment hypothesis (Gordon \& Pound, 1993) implies that firm's demand on independent director decreases as institutional investor shareholding increases.

Third, greater insider shareholding (Inside) reduces agency cost and enhances performance (Jensen, 1993). Similarly, establishment of alignment hypothesis (Jensen, 1993) implies that firm's demand on independent director (to monitoring the management) increases as insider shareholding increases. Alternatively, establishment of enchantment hypothesis (Gordon \& Pound, 1993) implies that firm's demand on independent director decreases as insider shareholding increases.

Chen and Lin (2011) also indicated that some financial characteristics act as determinants of board independence. First, firm's profitability (Profit), proxied by returns on equity, has influences on firm's decision on introducing independent director. Self-selection hypothesis predicts independent director is more willingness to be employed by firm with greater profitability due to better pay or lower risk. Thus, firm with greater profitability tends to have greater degree of board independence. On the contrary, performance improvement hypothesis predicts that firm with bad performance tends to search for independent director to play managerial monitoring and advising function. ${ }^{9}$ Thus, firm with greater profitability tends to have smaller probability of introducing independent director.

Second, size (Lnasset), acts as one determinant of firm's introducing independent director. O'Reilly, McDonnell, Winograd, Gerson, and Jaenicke (1998) indicated that firm with larger size tends to have superior inside control system and monitoring mechanism, so the demand of introducing independent director is lower. However, Watts and Zimmerman (1986) proposed that firm with larger size received greater public attention by government and 
investors. Candidates of independent director themselves are also likely to accept the offer from large firm because of higher reputation. Therefore, firm with larger size tends to have greater degree of board independence.

Third, Jensen and Meckling (1976) and Sengupta (1998) proposed that creditor also plays monitoring function and can be a substitute for independent director on managerial monitoring. Thus, higher debt ratio (Debt) is associated with lower probability of introducing independent director. On the other hand, firm with higher debt ratio tends to have greater bankruptcy risk and need independent director to exert their managerial monitoring and advising function. Thus, higher debt ratio is associated with greater degree of board independence.

Based on Rosenbaum and Rubin (1983, 1985a,b), use of propensity score matching requires estimating the propensity scores function based on the Probit model, which is

$$
\begin{aligned}
\left.\operatorname{probit}_{(I D} d_{i, t}=1\right)=\beta_{0} & +\beta_{1} \text { Outside }_{i, t}+\beta_{2} \text { Insthold }_{i, t}+\beta_{3} \text { Inside }_{i, t} \\
& +\beta_{4} \text { Profit }_{i, t}+\beta_{5} \text { Lnasset }_{i, t}+\beta_{6} \text { Debt }_{i, t}+\varepsilon_{i, t}
\end{aligned}
$$

where $I D \_d$ is equal to 1 if the sample firm has at least one independent director, and 0 otherwise. Outside is outside block shareholding, defined as the number of shares hold by outsider (not director, supervisors, managers and CEOs) block shareholders (more than 5\%) divided by total number of shares outstanding. Insthold is institutional investor's shareholding, defined as the number of shares hold by institutions (including domestic financial institutions, foreign Financial Institutions, domestic trust funds and offshore trust funds) divided by total number of shares outstanding. Inside, insider's shareholding, defined as the number of shares hold by insiders (including director, supervisor and managers and CEOs) divided by total number of shares outstanding. Profit, firm's profitability, proxied by returns on equity. Lnasset, proxy for firm size, defined as natural logarithm of total assets. Debt, debt ratio, defined as firm's total liability divided by total equity. The mnemonics and definition of variable are reported in Table 1.

\begin{tabular}{|c|c|}
\hline Variable & Definition \\
\hline ID_d & A dummy variable which equal to 1 if firm has at least one independent director. Otherwise, it is equal to 0 . \\
\hline ID_num & The number of independent directors. \\
\hline$I D \_r$ & The number of independent director divided by total number of director. \\
\hline Outside & $\begin{array}{l}\text { The number of share hold by outsider (not director, supervisors, managers and CEOs) block shareholders } \\
\text { (more than 5\%) divided by total number of shares outstanding. }\end{array}$ \\
\hline Insthold & $\begin{array}{l}\text { The number of share hold by institutions (including domestic financial institutions, foreign Financial } \\
\text { Institutions, domestic trust funds and offshore trust funds) divided by total number of share outstanding. }\end{array}$ \\
\hline Inside & $\begin{array}{l}\text { The number of share hold by insiders (including director, supervisor and managers and CEOs) divided by total } \\
\text { number of share outstanding. }\end{array}$ \\
\hline Profit & Returns on equity, after-tax net income divided by total equity \\
\hline Lnasset & Natural logarithm of total assets \\
\hline Debt & Total liability divided by total equity \\
\hline Rd & Research and development expense divided by net sales \\
\hline Salesgrowth & The annual growth rate of net sales \\
\hline CDdummy & A dummy variable such that as long as a firm pays cash dividend, it is equal to 1 , and 0 otherwise. \\
\hline MTB & The ratio of market value to book value of common equity. \\
\hline StockRet & Standard deviation of firm's daily stock returns. \\
\hline ExecuPayT & Total amount of executive compensation \\
\hline ExecuPayA & $\begin{array}{l}\text { Total amount of executive compensation divided by the number of managers (including CEO) who receives } \\
\text { compensation. }\end{array}$ \\
\hline ExecuPayR & The ratio of total amount of executive compensation to firm's earnings. \\
\hline Board & The number of directors \\
\hline CEOhold & The number of shares hold by CEO divided by total number of shares outstanding \\
\hline Pledge & $\begin{array}{l}\text { The average pledge ratio of all directors, where pledge ratio is defined as the number of share pledged by a } \\
\text { director divided by the number of share holds. }\end{array}$ \\
\hline Age & The number of year since company's establishment \\
\hline$Y D$ & A vector of yearly dummy variable \\
\hline IND & A vector of industry dummy variable \\
\hline
\end{tabular}

Table 1. Mnemonics and definition of variables

Note. The definition of variables comes from the Taiwan Economic Journal (TEJ). 


\subsection{Econometric Model}

This paper employs two ways to examine the effects of board independence on executive compensation and corporate performance. First, test of mean difference of specific outcome between two groups of samples, namely, firms with independent director and firms with independent director. The test is based on five pairs of samples. One pair is before-matching samples and four pairs are after-matching samples based on four matching algorithms. Bootstrapping methods with 1,000 repetitions are used to establish critical values to judge the statistically significance of the mean difference between two groups of samples.

Second, relating outcome variable to board independence and other control variables by multiple regression. To examine the effect of board independence on corporate performance, we run the following regression:

$$
\begin{aligned}
\text { Profit }_{i, t}=\beta_{0}+\beta_{1} I_{i, t} & +\beta_{2} \ln \text { asset }_{i, t}+\beta_{3} \text { Debt }_{i, t}+\beta_{4} \text { Salesgrowth }_{i, t}+\beta_{5} \text { Rd }_{i, t} \\
& +\beta_{6} \text { Board }_{i, t}+\beta_{7} \text { CEOhold }_{i, t}+\beta_{8} \text { Pledge }_{i, t}+\beta_{9} \text { Insthold }_{i, t} \\
& +\beta_{10} \text { Age }_{i, t}+\gamma Y D+\delta I N D+\varepsilon_{i, t}
\end{aligned}
$$

where Profit is proxied for firm's profitability, measured by returns on equity. $I D$ is the measurement of board independence, proxied by three variables, $I D_{-} d, I D_{-}$num and $I D_{-} r$. Based on the existing studies, several variables are controlled for firm's profitability. Total assets (Lnasset), controls for scale effect, defined as natural $\log$ of total assets. Debt ratio (Debt), controls for leverage effect, defined as the ratio of total debt to total equity. Sales growth (Salesgrowth), controls for growth opportunity, defined as annual growth rate of net sales. Research and development expense ratio $(R d)$, controls for innovation effect, defined as the ratio of research and development expense to net sales. The age of firm, Age, controls for leaning and reputational effect, defined as the number of year since company's establishment (Morck, Shleifer, \& Vishny, 1988; Demsetz \& Villalonga, 2001; McConnell \& Servaes, 1990).

We also incorporate corporate governance variables as controls for firm's profitability. Board size (Board), controls for board efficiency, defined as the total number of director. CEO shareholding (CEOhold), controls for the effect of CEO's interests-alignment/wealth-enchantment on firm's operating outcomes, defined as the number of shares hold by CEO divided by total number of shares outstanding. Pledge ratio for director's shareholding (Pledge), computed by the average pledge ratio of all directors, where pledge ratio is defined as the number of share pledged by a director divided by the number of shares hold. Institutional investor shareholding (Insthold), controls for institutional investor's better informational and knowledge on monitoring as well as incentive to enchant minority shareholder's wealth, defined as the number of shares hold by institutional investor divided by shares outstanding (Jensen \& Meckling, 1976; Leland \& Pyle, 1977; Jensen \& Ruback, 1983; Stulz, 1988; Yermack, 1996; Claessens, Djankov, \& Lang, 2000, Fich \& Shivdasani, 2006).

While data of the research covers 11 years and 18 industries, thus 10 yearly dummies $(Y D)$ and 17 industrial dummies $(I N D)$ are also incorporated into the regression equation to control for industry effect and macroeconomic condition on firm's profitability (Cagwin \& Bouwman, 2002; Ittner, Lanen, \& Larcker, 2002; Jones \& Kato, 1995).

To examine the effect of board independence on executive compensation, the regression equation is:

$$
\begin{aligned}
& \text { ExecuPay }_{i, t}=\beta_{0}+\beta_{1} I D_{i, t}+\beta_{2} \ln \text { asset }_{i, t}+\beta_{3} \text { Debt }_{i, t}+\beta_{4} \text { CDdummy }_{i, t}+\beta_{5} \text { Profit } t_{i, t} \\
& +\beta_{6} \text { MTB }_{i, t}+\beta_{7} \text { Stock } \operatorname{Ret}_{i, t}+\beta_{8} \text { Board }_{i, t}+\beta_{9} \text { CEOhold }_{i, t} \\
& +\beta_{10} \text { Insthold }_{i, t}+\gamma Y D+\delta I N D+\varepsilon_{i, t}
\end{aligned}
$$

where ExecuPay measures executive compensation, which is proxied by three variables. First, ExecuPayT, defined as the total amount of executive compensation. Second, ExecuPayA, the average amount of executive compensation, defined as the total amount of executive compensation divided by the number of managers (including CEO) who receives compensation. Third, ExecuPayR, defined as the ratio of total amount of executive compensation to firm's earnings. Similarly, in addition to $I D$, other variables are incorporated into the regression equation to control for the effects of size, leverage, dividend payout, operating performance, growth opportunities, idiosyncratic risk and corporate governance on executive compensation (Chen, Yi, \& Lin, 2013). CDdummy is a dummy variable such that as long as a firm pays cash dividend, it is equal to 1 , and 0 otherwise. $M T B$ is the ratio of market value to book value of common equity. StockRet is standard deviation of firm's daily stock returns. Other variables are mentioned before.

\section{Empirical Results}

\subsection{Descriptive Statistics}

In this research, totally 5,104 firm-year samples, the number of samples with/without independent director are 
603 and 4,501, respective. Table 2 reports descriptive statistics. We observe that mean of firm with independent director tends to be lower on Outside (17.954\% versus $18.252 \%$ ), Insthold $(37.439 \%$ versus $38.425 \%$ ), Inside (22.435\% versus $24.029 \%)$ and Debt $(71.857 \%$ versus $101.61 \%)$ than firm without independent director. On average, firm with independent director tends to have higher Profit $(8.4623 \%$ versus $3.5623 \%)$ but share similarity on Lnasset (15.776\% versus $15.762 \%$ ) with firm without independent director. Gordon and Pound, 1993) mentioned that outside block shareholder, institutional investor and insider shareholder have own private interest and are reluctant to be monitored by independent director. The result here shows that firm with independent director has lower outside and inside shareholding and lower institutional shareholdings, and thus consistent with enchantment hypothesis. Firm with independent director tends to have better profitability, and the result is consistent with self-selection hypothesis. Firm with independent tends to have lower debt ratio, the result consists with Jensen and Meckling (1976) and Sengupta (1998). Totally, the evidence of difference on observables between firm with/without independent director shows that potential sample selection bias is exist.

Higher mean on Profit of firm with independent director represents that more profitable firm tends to have greater degree of board independence. We also observe that, on the average, firm with independent director has higher ExecuPayT (40994 and 27371) and ЕxecuPayA (5233.7 versus 4243.3). Yet, firm with independent director tends to pay less in terms of total pay to firm's earnings (ExecuPayR: $11.612 \%$ versus $14.429 \%$ ).

Table 3 reports pair-wise Pearson correlation coefficients. We observe that, first, correlations between three proxies for board independence and Outside, Insthold and Inside are negative, and some them are significant and none of them is significantly positive. Second, correlations between three proxies for board independence and Profit are all significantly positive. Third, correlations between three proxies for board independence and Debt are all significantly negative. ID_num and Lnasset are positively correlated. Overall, the result of Table 3 is consistent with comparison for descriptive statistics.

\subsection{Sample Matching}

Table 4 presents the Probit estimation result of propensity score function. Estimated coefficient of Inside is negative and significant (-0.005), yet estimated coefficients of Outside and Insthold are negative but insignificant. Estimated coefficients of Profit and Debt are significantly positive and negative, respectively, means that firm with superior and lower debt ratio tends to introducing independent director. Give estimated propensity score function, for each sample, estimated probability (propensity score) of introducing independent director is obtained.

Table 5 reports mean difference on observables for sample selection. While whole samples are used in Table 2, only matched samples (have complete data on six observables) are employed here. While before matching, mean difference on Inside, Profit and Debt between firms with versus without independent director are significant, means of two groups of firm become approximately equal. Under four pairs of after-matching samples, differences in mean on six observables are insignificantly different from zero and magnitude of mean differences are also reduced (Note 10). However, the number of matching samples through Mahala Caliper matching is only five.

Table 6 reports percentage changes in mean difference of observables through sample matching. Because the average percentage changes in mean difference are $80.3 \%$ and $72.7 \%$ under Mahala and Mahala Caliper matching, they are regarded as more effective than another two. However, effective matching is not without cost. As mentioned before, the number of matched samples is substantially reduced under Mahala Caliper matching. The Nearest and Caliper matching are less effective matchings because of lower average percentage changes in mean difference during matching. Nevertheless, the number of observation did not largely decrease and still kept as 589 and 588. Overall, there is a trade-off between the effectiveness of matching and the degrees of freedom after matching. 
Table 2. Descriptive statistics

\begin{tabular}{|c|c|c|c|c|c|c|c|c|c|c|c|c|}
\hline \multirow[t]{2}{*}{ Variable } & \multicolumn{4}{|c|}{ Panel A. All Samples } & \multicolumn{4}{|c|}{$\begin{array}{c}\text { Panel B. Samples with at least one Ind. } \\
\text { Director }\end{array}$} & \multicolumn{4}{|c|}{ Panel C. Samples without Ind. Director } \\
\hline & Mean & Ste. Dev. & Min. & Max. & Mean & Ste. Dev. & Min. & Max. & Mean & Ste. Dev. & Min. & Max. \\
\hline ID_d & 0.1244 & 0.3301 & 0.0000 & 1.0000 & 1.0000 & 0.0000 & 1.0000 & 1.0000 & 0.0000 & 0.0000 & 0.0000 & 0.0000 \\
\hline ID_num & 0.2161 & 0.6276 & 0.0000 & 4.0000 & 1.7380 & 0.7229 & 1.0000 & 4.0000 & 0.0000 & 0.0000 & 0.0000 & 0.0000 \\
\hline$I D \_r$ & 3.1963 & 9.2845 & 4.7600 & 60.000 & 25.692 & 10.723 & 4.7600 & 60.000 & 0.0000 & 0.0000 & 0.0000 & 0.0000 \\
\hline Outside & 18.215 & 11.868 & 0.0000 & 81.330 & 17.954 & 11.719 & 0.0000 & 73.510 & 18.252 & 11.890 & 0.0000 & 81.330 \\
\hline Insthold & 38.303 & 21.975 & 0.0000 & 98.390 & 37.439 & 22.264 & 0.6300 & 97.070 & 38.425 & 21.933 & 0.0000 & 98.390 \\
\hline Inside & 23.831 & 13.980 & 0.1900 & 95.330 & 22.435 & 13.381 & 1.2300 & 79.850 & 24.029 & 14.053 & 0.1900 & 95.330 \\
\hline Profit & 4.1741 & 19.271 & -240.55 & 233.71 & 8.4623 & 15.251 & -140.97 & 64.270 & 3.5623 & 19.704 & -240.55 & 233.71 \\
\hline Lnasset & 15.764 & 1.1851 & 11.700 & 20.170 & 15.776 & 1.2873 & 13.430 & 20.170 & 15.762 & 1.1700 & 11.700 & 19.960 \\
\hline Debt & 97.892 & 288.70 & 1.2900 & 11451.4 & 71.857 & 56.101 & 4.2800 & 373.89 & 101.61 & 307.71 & 1.2900 & 11451.4 \\
\hline$R d$ & 1.8525 & 3.8774 & 0.0000 & 80.340 & 3.562 & 4.8656 & 0.0000 & 34.330 & 1.6090 & 3.6515 & 0.0000 & 80.340 \\
\hline Salesgrowth & 30.732 & 1119.9 & -134.40 & 75718.5 & 10.798 & 51.962 & -134.40 & 991.69 & 33.578 & 1197.0 & -100.00 & 75718.5 \\
\hline CDdummy & 0.6162 & 0.4864 & 0.0000 & 1.0000 & 0.7114 & 0.4535 & 0.0000 & 1.0000 & 0.6031 & 0.4893 & 0.0000 & 1.0000 \\
\hline MTB & 1.3460 & 1.0570 & 0.0400 & 24.060 & 1.5313 & 0.9204 & 0.2400 & 6.6900 & 1.3204 & 1.0720 & 0.0400 & 24.060 \\
\hline StockRet & 2.6598 & 0.8102 & 0.5500 & 6.3200 & 2.4865 & 0.6980 & 0.5700 & 4.7700 & 2.6836 & 0.8217 & 0.5500 & 6.3200 \\
\hline ExecuPayT & 29104 & 82054 & 4.0000 & 1791128 & 40994 & 126951 & 1204.0 & 1791128 & 27371 & 73120 & 4.0000 & 1272779 \\
\hline ЕхесиРауA & 4369.3 & 6131.0 & 4.0000 & 137779 & 5233.7 & 9634.9 & 611.00 & 137779 & 4243.3 & 5426.0 & 4.0000 & 89581 \\
\hline ExecuPayR & 14.056 & 93.461 & 0.0100 & 3445.5 & 11.612 & 40.832 & 0.0400 & 505.40 & 14.429 & 99.068 & 0.0100 & 3445.5 \\
\hline Board & 7.2184 & 2.9805 & 3.0000 & 26.000 & 7.1111 & 2.3750 & 4.0000 & 21.000 & 7.2336 & 3.0568 & 3.0000 & 26.000 \\
\hline CEOhold & 1.1076 & 2.0965 & 0.0000 & 19.930 & 1.4337 & 1.9849 & 0.0000 & 11.930 & 1.0613 & 2.1081 & 0.0000 & 19.930 \\
\hline Pledge & 14.878 & 22.232 & 0.0000 & 100.00 & 11.137 & 18.632 & 0.0000 & 87.090 & 15.409 & 22.649 & 0.0000 & 100.00 \\
\hline Age & 32.225 & 11.822 & 1.0000 & 66.000 & 26.572 & 10.436 & 2.0000 & 62.000 & 33.028 & 11.789 & 1.0000 & 66.000 \\
\hline
\end{tabular}

Note. Yearly data is ranged from 2001 to 2011 . Samples with and without at least one independent director are 603 and 4,501, respectively.

Table 3. Correlation matrix

\begin{tabular}{|c|c|c|c|c|c|c|c|c|c|c|}
\hline Variable & $(1)$ & (2) & (3) & (4) & (5) & (6) & (7) & (8) & (9) & $(10)$ \\
\hline (1) $I D \_d$ & 1.0000 & & & & & & & & & \\
\hline (2) ID_num & $0.9139^{*}$ & 1.0000 & & & & & & & & \\
\hline (3) $\boldsymbol{I D} \_r$ & $0.9134^{*}$ & $0.9571 *$ & 1.0000 & & & & & & & \\
\hline (4) Outside & -0.0085 & -0.0070 & 0.0004 & 1.0000 & & & & & & \\
\hline (5) Insthold & -0.0150 & 0.0096 & -0.0073 & $0.2463^{*}$ & 1.0000 & & & & & \\
\hline (6) Inside & $-0.0379^{*}$ & $-0.0261^{*}$ & -0.0213 & $-0.1840^{*}$ & $0.3837^{*}$ & 1.0000 & & & & \\
\hline (7) Profit & $0.0837^{*}$ & $0.0772^{*}$ & $0.0885^{*}$ & $0.0512 *$ & $0.2043^{*}$ & $0.0875^{*}$ & 1.0000 & & & \\
\hline (8) Lnasset & 0.0037 & $0.0423^{*}$ & -0.0014 & $-0.1265^{*}$ & $0.3359^{*}$ & $-0.1097^{*}$ & $0.1690^{*}$ & 1.0000 & & \\
\hline (9) Debt & $-0.0335^{*}$ & $-0.0301 *$ & $-0.0295^{*}$ & -0.0053 & -0.0039 & $0.0289 *$ & $-0.3967 *$ & -0.0146 & 1.0000 & \\
\hline (10) $R d$ & $0.1662^{*}$ & $0.1352^{*}$ & $0.1396^{*}$ & $-0.1189^{*}$ & $-0.1029 *$ & $-0.0729 *$ & $-0.0720^{*}$ & 0.0194 & $-0.0589 *$ & 1.0000 \\
\hline (11) Salesgrowth & -0.0067 & -0.0063 & -0.0062 & 0.0105 & 0.0023 & 0.0022 & 0.0209 & 0.0100 & 0.0009 & -0.0128 \\
\hline (12) CDdummy & $0.0800^{*}$ & $0.0738^{*}$ & $0.0857^{*}$ & 0.0223 & $0.2292 *$ & $0.1408^{*}$ & $0.4959 *$ & $0.1882 *$ & $-0.1509 *$ & -0.0056 \\
\hline (13) $M T B$ & $0.0702^{*}$ & $0.0556^{*}$ & $0.0723^{*}$ & $0.0955^{*}$ & $0.2552 *$ & $0.0789^{*}$ & $0.1554 *$ & $0.0670^{*}$ & $0.2662 *$ & $0.1030^{*}$ \\
\hline (14) StockRet & $-0.0846^{*}$ & $-0.0777^{*}$ & $-0.0797^{*}$ & $-0.1063^{*}$ & $-0.2053^{*}$ & $-0.1547 *$ & $-0.3168^{*}$ & $-0.1181^{*}$ & $0.1709^{*}$ & $0.0469 *$ \\
\hline (15) ExecuPayT & $0.1370^{*}$ & $0.1876^{*}$ & $0.1448^{*}$ & $-0.0568^{*}$ & $0.1598^{*}$ & $-0.0716^{*}$ & $0.1326^{*}$ & $0.3598^{*}$ & -0.0281 & $0.0837 *$ \\
\hline (16) ЕхесиРауA & $0.1001^{*}$ & $0.1516^{*}$ & $0.1098^{*}$ & $-0.0699^{*}$ & $0.1904^{*}$ & $-0.0697^{*}$ & $0.2281^{*}$ & $0.3468^{*}$ & $-0.0530 *$ & $0.0671^{*}$ \\
\hline (17) ExecuPayR & -0.0131 & -0.0173 & -0.0159 & -0.0177 & $-0.0571^{*}$ & 0.0051 & $-0.1044^{*}$ & $-0.0905^{*}$ & 0.0024 & 0.0241 \\
\hline (18) Board & -0.0140 & 0.0188 & $-0.0528^{*}$ & $-0.1366^{*}$ & $0.1902 *$ & $0.0673 *$ & $0.0422 *$ & $0.3143^{*}$ & -0.0171 & $-0.0580 *$ \\
\hline (19) CEOhold & $0.0586^{*}$ & $0.0393^{*}$ & $0.0437 *$ & $-0.0660^{*}$ & $-0.1954 *$ & $0.0830^{*}$ & $0.0497^{*}$ & $-0.0744 *$ & $-0.0388^{*}$ & $0.1014 *$ \\
\hline (20) Pledge & $-0.0635^{*}$ & $-0.0589 *$ & $-0.0631^{*}$ & -0.0094 & -0.0133 & $-0.1506^{*}$ & $-0.1161^{*}$ & $0.1096^{*}$ & $0.0590^{*}$ & $-0.0518 *$ \\
\hline (21) Age & $-0.1804^{*}$ & $-0.1701^{*}$ & $-0.1772^{*}$ & $0.1010^{*}$ & 0.0091 & $-0.0619^{*}$ & 0.0095 & $0.0818^{*}$ & 0.0065 & $-0.2611 *$ \\
\hline
\end{tabular}

Note. This table reports Pearson correlation coefficients among variables. Correlation coefficient followed by an asterisk means that it is at least $10 \%$ significantly different from zero. 
Table 3. Correlation matrix (continue)

\begin{tabular}{|c|c|c|c|c|c|c|c|c|c|c|c|}
\hline Variable & $(11)$ & $(12)$ & (13) & (14) & $(15)$ & $(16)$ & $(17)$ & $(18)$ & (19) & $(20)$ & $(21)$ \\
\hline \multicolumn{12}{|l|}{ (1) $I D \_d$} \\
\hline \multicolumn{12}{|l|}{ (2) ID_num } \\
\hline \multicolumn{12}{|l|}{ (3) $\boldsymbol{I D} \_r$} \\
\hline \multicolumn{12}{|l|}{ (4) Outside } \\
\hline \multicolumn{12}{|l|}{ (5) Insthold } \\
\hline \multicolumn{12}{|l|}{ (6) Inside } \\
\hline \multicolumn{12}{|l|}{ (7) Profit } \\
\hline \multicolumn{12}{|l|}{ (8) Lnasset } \\
\hline \multicolumn{12}{|l|}{ (9) Debt } \\
\hline \multicolumn{12}{|l|}{ (10) $R \boldsymbol{d}$} \\
\hline (11) Salesgrowth & 1.0000 & & & & & & & & & & \\
\hline (12) CDdummy & 0.0087 & 1.0000 & & & & & & & & & \\
\hline (13) $M T B$ & 0.0056 & $0.2338^{*}$ & 1.0000 & & & & & & & & \\
\hline (14) StockRet & 0.0227 & $-0.3962 *$ & $-0.0388 *$ & 1.0000 & & & & & & & \\
\hline (15) ExecuРayT & 0.0016 & $0.1578^{*}$ & $0.1723^{*}$ & $-0.0849^{*}$ & 1.0000 & & & & & & \\
\hline (16) ЕхесиРауA & 0.0007 & $0.2342^{*}$ & $0.2495^{*}$ & $-0.0965^{*}$ & $0.8193^{*}$ & 1.0000 & & & & & \\
\hline (17) ExecuPayR & -0.0039 & $-0.1777^{*}$ & $-0.0713^{*}$ & $0.0585^{*}$ & -0.0240 & -0.0330 & 1.0000 & & & & \\
\hline (18) Board & -0.0160 & $0.0643^{*}$ & $-0.0378^{*}$ & $-0.1514 *$ & $0.0608^{*}$ & $0.0891^{*}$ & $-0.0352 *$ & 1.0000 & & & \\
\hline (19) CEOhold & -0.0089 & $0.0626^{*}$ & $0.0488^{*}$ & -0.0025 & $0.0433^{*}$ & 0.0155 & 0.0222 & $-0.0529 *$ & 1.0000 & & \\
\hline (20) Pledge & $0.0273^{*}$ & $-0.1039^{*}$ & $-0.1030^{*}$ & $0.0754 *$ & 0.0058 & -0.0248 & -0.0201 & $-0.0255^{*}$ & $-0.0831^{*}$ & 1.0000 & \\
\hline (21) $A g e$ & -0.0018 & $0.0283^{*}$ & $-0.1836^{*}$ & $-0.1651^{*}$ & $-0.1453^{*}$ & $-0.1446^{*}$ & -0.0316 & $0.1980 *$ & $-0.1979 *$ & $0.0775^{*}$ & 1.0000 \\
\hline
\end{tabular}

Table 4. Estimation result of propensity score function

\begin{tabular}{lc}
\hline Variable & Estimated Coefficients \\
\hline Constant & -0.6322 \\
& $(-1.63)$ \\
Outside & -0.0027 \\
& $(-1.17)$ \\
Insthold & -0.0006 \\
& $(-0.41)$ \\
Inside & $-0.0055^{* *}$ \\
& $(-2.56)$ \\
Profit & $0.0092^{* * *}$ \\
Lnasset & $(5.65)$ \\
Debt & -0.0201 \\
Num. of Observations & $(-0.84)$ \\
Pseudo $R^{2}$ & $-0.0007^{* *}$ \\
\hline
\end{tabular}

Note. Based on all samples, this table reports Probit estimation of propensity score function. The number in parentheses below estimated coefficients are $t$-statistics. ${ }^{* * *},{ }^{* *}$ and ${ }^{*}$ denote the significance at the $1 \%, 5 \%$ and $10 \%$ levels, respectively.

\subsection{Univariate Analysis of Corporate Performance and Executive Compensation}

Table 7 reports mean difference on corporate performance and executive compensation between samples with versus without independent director. Before matching, three proxies for corporate performance of firm with independent director are significantly larger. Yet, under four pairs of after-matching samples, the evidence of significantly superior on performance for firm with independent director is largely decreased. However, under Mahala matching, firm with independent director still perform better on Profit and ROS. After matching treated sample by control sample with six observables, outperformance on firm with independent director is insignificant. 
Before matching, firm with independent director tends to have higher ExecuPayT and ExecuPayA. Under four pairs of matching samples, the evidence of higher ExecuPayT and ExecuPayA of firm with independent director is still maintained. After matching treated sample by control sample with six observables, higher total and average pay to executive by firm with independent director is still significant.

Table 5. Mean difference on observables for sample selection: before-matching samples and after-matching samples

\begin{tabular}{|c|c|c|c|c|c|c|c|c|c|c|c|c|c|c|c|}
\hline \multirow[b]{3}{*}{ Variable } & \multirow{2}{*}{\multicolumn{3}{|c|}{ Panel A. Before Matching }} & \multicolumn{12}{|c|}{ Panel B. After-Matching by Four Algorithms } \\
\hline & & & & \multicolumn{3}{|c|}{ Nearest } & \multicolumn{3}{|c|}{ Caliper } & \multicolumn{3}{|c|}{ Mahala } & \multicolumn{3}{|c|}{ Mahala Caliper } \\
\hline & $\begin{array}{l}\text { Samples } \\
\text { with Ind. } \\
\text { Director }\end{array}$ & $\begin{array}{c}\text { Samples } \\
\text { without Ind } \\
\text { Director }\end{array}$ & $\begin{array}{c}\text { Diff. in } \\
\text { Mean } \\
\text { (t-value) }\end{array}$ & $\begin{array}{l}\text { Samples } \\
\text { with Ind. } \\
\text { Director }\end{array}$ & $\begin{array}{c}\text { Samples } \\
\text { without Ind } \\
\text { Director }\end{array}$ & $\begin{array}{l}\text { Diff. in } \\
\text { Mean } \\
\text { (t-value) }\end{array}$ & $\begin{array}{l}\text { Samples } \\
\text { with Ind. } \\
\text { Director }\end{array}$ & $\begin{array}{c}\text { Samples } \\
\text { without Ind. } \\
\text { Director }\end{array}$ & $\begin{array}{c}\text { Diff. in } \\
\text { Mean } \\
\text { (t-value) }\end{array}$ & $\begin{array}{l}\text { Samples } \\
\text { with Ind. } \\
\text { Director }\end{array}$ & $\begin{array}{c}\text { Samples } \\
\text { without Ind. } \\
\text { Director } \\
\end{array}$ & $\begin{array}{l}\text { Diff. in } \\
\text { Mean } \\
\text { (t-value) }\end{array}$ & $\begin{array}{l}\text { Samples } \\
\text { with Ind. } \\
\text { Director }\end{array}$ & $\begin{array}{c}\text { Samples } \\
\text { without Ind. } \\
\text { Director }\end{array}$ & $\begin{array}{l}\text { Diff. in } \\
\text { Mean } \\
\text { (t-value) } \\
\end{array}$ \\
\hline Outside & 18.000 & 18.297 & $\begin{array}{l}-0.2970 \\
(-0.57)\end{array}$ & 18.000 & 18.542 & $\begin{array}{c}-0.5420 \\
(-0.81)\end{array}$ & 18.005 & 18.562 & $\begin{array}{c}-0.5570 \\
(-0.83)\end{array}$ & 18.000 & 17.897 & $\begin{array}{c}0.1030 \\
(0.15)\end{array}$ & 15.805 & 15.835 & $\begin{array}{c}-0.0300 \\
(-0.01)\end{array}$ \\
\hline Insthold & 37.102 & 37.946 & $\begin{array}{c}-0.8440 \\
(-0.88)\end{array}$ & 37.102 & 37.303 & $\begin{array}{c}-0.2010 \\
(-0.16)\end{array}$ & 37.130 & 37.302 & $\begin{array}{c}-0.1720 \\
(-0.14)\end{array}$ & 37.102 & 36.869 & $\begin{array}{c}0.2330 \\
(0.18)\end{array}$ & 59.158 & 59.235 & $\begin{array}{c}-0.0770 \\
(0.00)\end{array}$ \\
\hline Inside & 22.545 & 24.014 & $\begin{array}{c}-1.4690^{* *} \\
(-2.40)\end{array}$ & 22.545 & 21.595 & $\begin{array}{l}0.9500 \\
(1.25)\end{array}$ & 22.573 & 21.583 & $\begin{array}{l}0.9900 \\
(1.30)\end{array}$ & 22.545 & 22.282 & $\begin{array}{c}0.2630 \\
(0.34)\end{array}$ & 29.882 & 29.895 & $\begin{array}{c}-0.0130 \\
(0.00)\end{array}$ \\
\hline Profit & 8.4623 & 3.6068 & $\begin{array}{c}1.8555^{*} \text { **: } \\
(5.77)\end{array}$ & 8.4623 & 7.9679 & $\begin{array}{c}0.4944 \\
(0.56)\end{array}$ & 8.3726 & 7.8690 & $\begin{array}{l}0.5036 \\
(0.57)\end{array}$ & 8.4623 & 7.9733 & $\begin{array}{c}0.4890 \\
(0.58)\end{array}$ & 4.8900 & 5.1150 & $\begin{array}{c}-0.2250 \\
(-0.05)\end{array}$ \\
\hline Lnasset & 15.776 & 15.763 & $\begin{array}{l}0.0130 \\
(0.25)\end{array}$ & 15.776 & 15.780 & $\begin{array}{c}-0.0040 \\
(-0.05)\end{array}$ & 15.775 & 15.777 & $\begin{array}{c}-0.0020 \\
(-0.04)\end{array}$ & 15.776 & 15.774 & $\begin{array}{l}0.0020 \\
(0.03)\end{array}$ & 15.530 & 15.548 & $\begin{array}{c}-0.0180 \\
(-0.01)\end{array}$ \\
\hline Debt & 71.857 & 100.98 & $\begin{array}{c}-29.123^{* *} \\
(-2.30)\end{array}$ & 71.857 & 70.413 & $\begin{array}{l}1.4440 \\
(0.43) \\
\end{array}$ & 71.849 & 70.486 & $\begin{array}{l}1.3630 \\
(0.40) \\
\end{array}$ & 71.857 & 68.076 & $\begin{array}{l}3.7810 \\
(1.25) \\
\end{array}$ & 24.333 & 25.723 & $\begin{array}{c}-1.3900 \\
(-0.17) \\
\end{array}$ \\
\hline
\end{tabular}

Note. This table reports mean and difference in mean for six observables determining board independence. Panel A is based on before matching samples, and the number of samples with and without independent director are 60 and 4,501, respectively. Panel B reports the result under four matching algorithms and the number of samples with independent director and after-matching sample without independent director are 589, 588, 589 and 4 . The $t$-statistics are presented in parentheses. ${ }^{* * *},{ }^{* *}$ and ${ }^{*}$ denote mean difference is significantly different from zero at the $1 \%, 5 \%$ and $10 \%$ levels, respectively.

Table 6. Percentage changes in mean difference of observables through sample matching

\begin{tabular}{ccccc}
\hline \multirow{2}{*}{ Variable } & \multicolumn{4}{c}{ Matching Algorithm } \\
\cline { 2 - 5 } & Nearest & Caliper & Mahala & Mahala Caliper \\
\hline Outside & -82.5 & -87.4 & 65.5 & 89.9 \\
Insthold & 76.1 & 79.6 & 72.5 & 90.8 \\
Inside & 35.3 & 32.6 & 82.1 & 99.1 \\
Profit & 89.8 & 89.6 & 89.9 & 95.4 \\
Lnasset & 70.0 & 80.4 & 84.5 & -34.5 \\
Debt & 95.0 & 95.3 & 87.0 & 95.2 \\
Average & 47.3 & 48.4 & 80.3 & 72.7 \\
\hline
\end{tabular}

Note. This table reports percentage changes in mean difference of six observables through sample matching Larger percentage change is associated with more effective matching.

Table 7. Mean difference on corporate performance and executive compensation between samples with and without independent director

\begin{tabular}{lccccc}
\hline \multirow{2}{*}{ Variable } & \multirow{2}{*}{ Before Matching } & \multicolumn{3}{c}{ After-Matching by Four Algorithms } \\
\cline { 3 - 6 } Profit & $4.8554^{* * * *}$ & Nearest & Caliper & Mahala & Mahala Caliper \\
\hline \multirow{2}{*}{ ROA } & $(5.77)$ & $(0.4944$ & 0.5036 & $0.4890^{*}$ & -0.2250 \\
& $2.7708^{* * *}$ & 0.6755 & $(0.84)$ & $(1.92)$ & $(-0.44)$ \\
\multirow{2}{*}{ ROS } & $(7.26)$ & $(1.46)$ & 0.7463 & 0.4696 & -1.0750 \\
& $3.1407^{* * *}$ & 0.0640 & $(1.62)$ & $(1.58)$ & $(-1.29)$ \\
\multirow{2}{*}{ ExecuPayT } & $(3.71)$ & $(0.05)$ & $(0.110)$ & $3.1470^{* * *}$ & 2.5650 \\
& $2219.7^{* * * *}$ & $17524.4^{* * *}$ & $17853.1^{* * *}$ & $(3.12)$ & $(1.37)$ \\
& $(7.38)$ & $(2.72)$ & $(2.84)$ & $(2.69)$ & $(2.22)$ \\
\hline
\end{tabular}




\begin{tabular}{lccccc}
\hline \multirow{2}{*}{ ExecuPayA } & $1505.38^{* * *}$ & 578.512 & 640.928 & $866.785^{*}$ & $1068.5^{* *}$ \\
& $(5.46)$ & $(1.01)$ & $(1.17)$ & $(1.79)$ & $(2.16)$ \\
ExecuPayR & -3.2663 & 2.7056 & 2.7056 & 1.8544 & N.A \\
\hline
\end{tabular}

Note. This table reports mean difference on three corporate performance (Profit, ROA and ROS) and three proxies for executive compensation (ExecuPayT, ExecuPayA and ExecuPayR) between samples with and without independent director. The bootstrap $t$-statistics are presented in the parentheses by repeating sampling 1,000 times. ${ }^{* * *},{ }^{* *}$ and ${ }^{*}$ denote that mean difference is significantly different from zero at the $1 \%, 5 \%$ and $10 \%$ level, respectively. The N.A means that we lack of data on ExecuPayR after matching.

\subsection{Multivariate Analysis}

Table 8 reports the OLS estimation result of the effect of introducing independent director on corporate performance. We hierarchically estimated multiple regression equation and did not report estimated coefficient on constant (Note 11). Before matching, no matter which model is employed, the estimated coefficient of $I D \_d$ is all significantly positive. After controlling other factors for operating performance, firm's introducing independent director is still associated with superior performance. Coefficients on controls generally show that firm with large scale, lower debt ratio, lower R\&D ratio, higher sales growth, smaller board size, higher CEO shareholding, lower pledge ratio and higher institutional shareholding tends to perform better on profitability.

The effect of introducing independent director on performance altered under four pairs of after-matching samples. No matter which matching algorithm is used and regardless of which model is estimated, all estimated coefficients on $I D \_d$ are insignificant, means that after matched sample for treated firm by control firm with similarity on ownership structure (Outside, Inside and Insthold) and firm characteristics (Profit, Lnasset and $D e b t$ ), significant outperformance of treated firm is vanished. The explanation is quite intuitive. The estimation result of propensity score function shows that more profitable firm tends to introducing independent director. We matched treated firm by control firm with similar on profitability (and other dimensions), thus the difference on profitability of treated firm and after-matching control firm is surely vanished.

Table 9 reports the OLS estimation result of the effect of the number of independent director on corporate performance. We observe that before matching, all coefficient of $I D \_n u m$ are significantly positive, means that greater number of independent director is associated with better performance. Coefficients on controls are generally consistent with the result in previous table. Under four pairs of after-matching samples, regardless of which model is estimated, coefficient on ID_num is insignificant, means that increasing the number of independent director helps little about firm performance. Explanation is intuitive and similar as before.

Table 10 reports the OLS estimation result of the effect of independent director ratio on corporate performance. We observe that before matching, all coefficient of $I D \_r$ are significantly positive, means that greater independent director ratio is correlated with better performance. Under four pairs of after-matching samples, significantly positive coefficient on $I D_{-} r$ is still exist. Evidence of significantly positive effect on corporate performance is more frequent on $I D \_r$ than $I D \_d$ and $I D \_n u m$. Recall that in Taiwan, the Article 14 of the "Securities and Exchange Act" requires that financial firms and firms with paid-in capital up to 50 billion NTD (or above) must set at least two independent directors and the independent director ratio cannot be less than $20 \%$. If the board size is relative large than the number of independent director, independent monitoring and advising function of the latter is diluted and limited. That's why independent director ratio, instead of the number of independent director, has larger and more significant effect on performance.

Table 11 reports estimation result of the effect of board independence on executive compensation. Board independence is proxied by $I D \_d$, ID_num and $I D \_r$, and executive compensation is proxied by ExecuPayT, ExecuPayA and ExecuPayR. Panel A is estimation result under before-matching samples. Panel B, C and D report estimation results under after-matching samples through Nearest, Caliper and Mahala matching. In panel A, when executive compensation is proxied by ExecuPayT, coefficients of $I D \_d$, ID_num and $I D \_r$ are significantly positive, means that the introducing independent director, the number of independent director and the independent director ratio are positively associated with greater total pay to executive. When executive compensation is proxied by ExecuPayA, similar result is obtained.

However, when executive compensation is proxied by ExecuPayR, estimated coefficient of $I D \_d, I D \_n u m$ and $I D \_r$ are all insignificantly, and the result is consistent with Table 3 and Table 7 whereas ExecuPayR is not significantly correlated with $I D \_d, I D \_n u m$ and $I D \_r$ and ExecuPay $R$ is not significantly different between firm with and without independent director. In Panel B, C and D, as long as executive compensation is proxied by ExecuPayT, coefficients on $I D \_d, I D \_n u m$ and $I D \_r$ are all positive and significant. Overall, the evidence generally shows that before matching, greater degree of board independence is associated with higher total pay 
and average pay to executive. After matching, board independence is only positively correlated with total pay but not average pay and ratio of pay to earnings.

Table 8 . The effect of introducing independent director on corporate performance-pooled OLS estimation

\begin{tabular}{|c|c|c|c|c|c|c|c|c|c|c|c|c|c|c|c|c|c|c|c|c|}
\hline \multirow{3}{*}{ Variable } & \multirow{2}{*}{\multicolumn{4}{|c|}{ Panel A. Before Matching }} & \multicolumn{16}{|c|}{ Panel B. After-Matching by Four Algorithms } \\
\hline & & & & & \multicolumn{4}{|c|}{ Nearest } & \multicolumn{4}{|c|}{ Caliper } & \multicolumn{4}{|c|}{ Mahala } & \multicolumn{4}{|c|}{ Mahala Caliper } \\
\hline & Model I & Model 2 & Model 3 & Model 4 & Model 1 & Model 2 & Model 3 & Model 4 & Model 1 & Model 2 & Model 3 & Model 4 & Model I & Model 2 & Model 3 & Model 4 & Model 1 & Model 2 & Model 3 & Model 4 \\
\hline$I D \_d$ & $\begin{array}{l}5.0464^{\prime \cdots} \\
(6.50)\end{array}$ & $\begin{array}{l}4.3872^{\cdots} \\
(5.35)\end{array}$ & $\begin{array}{l}4.7869^{\circ} \\
(6.31)\end{array}$ & $\begin{array}{l}4.1348 \cdots \\
(5.41)\end{array}$ & $\begin{array}{l}0.9504 \\
(1.05)\end{array}$ & $\begin{array}{l}0.3910 \\
(0.45)\end{array}$ & $\begin{array}{l}1.0771 \\
(1.22)\end{array}$ & $\begin{array}{l}0.3838 \\
(0.41)\end{array}$ & $\begin{array}{l}1.1010 \\
(1.23)\end{array}$ & $\begin{array}{l}0.5124 \\
(0.60)\end{array}$ & $\begin{array}{l}1.2318 \\
(1.40)\end{array}$ & $\begin{array}{l}0.5273 \\
(0.56)\end{array}$ & $\begin{array}{l}1.2019 \\
(1.46)\end{array}$ & $\begin{array}{l}0.4466 \\
(0.55)\end{array}$ & $\begin{array}{l}1.2821 \\
(1.61)\end{array}$ & $\begin{array}{l}0.6338 \\
(0.74)\end{array}$ & $\begin{array}{l}4.8436 \\
(0.65)\end{array}$ & $\begin{array}{l}4.9601 \\
(0.68)\end{array}$ & $\begin{array}{l}4.7312 \\
(0.66)\end{array}$ & $\begin{array}{l}-0.7498 \\
(-0.10)\end{array}$ \\
\hline Lnasset & $\begin{array}{l}2.6679^{\cdots} \\
(12.6)\end{array}$ & & $\begin{array}{l}2.2478^{\cdots *} \\
(9.76)\end{array}$ & $\begin{array}{l}2.1184^{\cdots} \\
(8.84)\end{array}$ & $\begin{array}{l}2.1613^{\cdots} \\
(6.17)\end{array}$ & & $\begin{array}{l}1.7231{ }^{\prime \cdots} \\
(4.43)\end{array}$ & $\begin{array}{l}1.5817^{\cdots \cdots} \\
(3.89)\end{array}$ & $\begin{array}{l}2.1150 \\
(6.06)\end{array}$ & & $\begin{array}{l}1.6619^{\cdots} \\
(4.29)\end{array}$ & $\begin{array}{l}1.5045^{\prime \prime} \\
(3.71)\end{array}$ & $\begin{array}{l}1.4466 \\
(4.47)\end{array}$ & & $\begin{array}{l}1.0970 \cdots \\
(3.11)\end{array}$ & $\begin{array}{l}0.6964^{\circ} \\
(1.85)\end{array}$ & $\begin{array}{l}1.2851^{\cdots} \\
(2.71)\end{array}$ & & $\begin{array}{l}1.4101^{\prime \cdots} \\
(2.65)\end{array}$ & $\begin{array}{l}0.9848^{\circ} \\
(1.67)\end{array}$ \\
\hline Debt & $\begin{array}{l}-0.0262^{\cdots} \\
(-30.0)\end{array}$ & & $\begin{array}{l}-0.02566^{*} \\
(-30.0)\end{array}$ & $\begin{array}{l}-0.0297 \\
(-31.5)\end{array}$ & $\begin{array}{l}-0.0619^{\cdots} \\
(-8.02)\end{array}$ & & $\begin{array}{l}-0.0588^{\prime \prime} \\
(-7,70)\end{array}$ & $\begin{array}{l}-0.05866^{\prime \prime} \\
(-7,71)\end{array}$ & $\begin{array}{l}-0.0612 \\
(-7.96)\end{array}$ & & $\begin{array}{l}-0.0580^{\prime \prime \prime} \\
(-7,64)\end{array}$ & $\begin{array}{l}-0.0578^{\cdots} \\
(-7.64)\end{array}$ & $\begin{array}{l}-0.0506 \\
(-6.34)\end{array}$ & & $\begin{array}{l}-0.0502^{\cdots} \\
(-6.48)\end{array}$ & $\begin{array}{l}-0.0511^{\prime \cdots} \\
(-0.68)\end{array}$ & $\begin{array}{l}-0.04566^{\cdots} \\
(-3.84)\end{array}$ & & $\begin{array}{l}-0.0480^{\cdots} \\
(-4.20)\end{array}$ & $\begin{array}{l}-0.0519^{\prime \cdots} \\
(-4.55)\end{array}$ \\
\hline$R d$ & $\begin{array}{l}-0.5854^{\cdots} \\
(-8.67)\end{array}$ & & $\begin{array}{l}-0.5245^{\cdots} \\
(-7.89)\end{array}$ & $\begin{array}{l}-0.6156^{\cdots} \\
(-8.92)\end{array}$ & $\begin{array}{l}-0.4372 \cdots \\
(-3.68)\end{array}$ & & $\begin{array}{l}-0.3351 \cdots \\
(-2.86)\end{array}$ & $\begin{array}{l}-0.3624 \cdots \\
(-3.06)\end{array}$ & $\begin{array}{l}-0.4342 \\
(-3.67)\end{array}$ & & $\begin{array}{l}-0.3312^{2 \cdots} \\
(-2.84)\end{array}$ & $\begin{array}{l}-0.3592^{\cdots} \\
(-3.05)\end{array}$ & $\begin{array}{l}-0.5510 \\
(-7.08)\end{array}$ & & $\begin{array}{l}-0.5048^{\cdots} \\
(-6.70)\end{array}$ & $\begin{array}{l}-0.5373^{\cdots} \\
(-7.06)\end{array}$ & $\begin{array}{l}-0.1340 \\
(-0.95)\end{array}$ & & $\begin{array}{l}-0.0808 \\
(-0.59)\end{array}$ & $\begin{array}{l}-0.1087 \\
(-0.79)\end{array}$ \\
\hline Salesgrowth & $\begin{array}{l}0.0003 \\
(1.43)\end{array}$ & & $\begin{array}{l}0.0004^{\circ} \\
(1.68)\end{array}$ & $\begin{array}{l}0.0004^{\circ} \\
(1.95)\end{array}$ & $\begin{array}{l}0.0001 \\
(0.34)\end{array}$ & & $\begin{array}{l}0.0001 \\
(0.39)\end{array}$ & $\begin{array}{l}0.0001 \\
(0.46)\end{array}$ & $\begin{array}{l}0.0001 \\
(0.35)\end{array}$ & & $\begin{array}{l}0.0001 \\
(0.39)\end{array}$ & $\begin{array}{l}0.0001 \\
(0.47)\end{array}$ & $\begin{array}{l}0.0022 \\
(2.11)\end{array}$ & & $\begin{array}{l}0.0016 \\
(1.63)\end{array}$ & $\begin{array}{l}0.0026^{\cdots} \\
(2.60)\end{array}$ & $\begin{array}{l}0.0568^{\circ *} \\
(4.73)\end{array}$ & & $\begin{array}{l}0.0493^{\cdots} \\
(4.31)\end{array}$ & $\begin{array}{l}0.0451^{\cdots} \\
(3.93)\end{array}$ \\
\hline Age & $\begin{array}{l}-0.0307 \\
(-1.34)\end{array}$ & & $\begin{array}{l}0.0289 \\
(1.24)\end{array}$ & $\begin{array}{l}-0.0253 \\
(-0.91)\end{array}$ & $\begin{array}{l}-0.0832{ }^{*} \\
(-2.00)\end{array}$ & & $\begin{array}{l}-0.0174 \\
(-0.41)\end{array}$ & $\begin{array}{l}0.0183 \\
(0.38)\end{array}$ & $\begin{array}{l}-0.0724^{\circ} \\
(-1.75)\end{array}$ & & $\begin{array}{l}-0.0088 \\
(-0.21)\end{array}$ & $\begin{array}{l}0.0259 \\
(0.54)\end{array}$ & $\begin{array}{l}-0.0310 \\
(-0.78)\end{array}$ & & $\begin{array}{l}0.0166 \\
(0.41)\end{array}$ & $\begin{array}{l}0.0418 \\
(0.92)\end{array}$ & $\begin{array}{l}0.0554 \\
(0.88)\end{array}$ & & $\begin{array}{l}0.1352^{*} \\
(2.14)\end{array}$ & $\begin{array}{l}0.1904^{* \cdots} \\
(2.67)\end{array}$ \\
\hline Board & & $\begin{array}{l}-0.0075 \\
(-0.08)\end{array}$ & $\begin{array}{l}-0.33899^{\cdots} \\
(-3.63)\end{array}$ & $\begin{array}{l}-0.3312 \cdots \\
(-3.53)\end{array}$ & & $\begin{array}{l}-0.4270^{*} \\
(-2.56)\end{array}$ & $\begin{array}{l}-0.7055^{\cdots} \\
(-3.97)\end{array}$ & $\begin{array}{l}-0.8087 \cdots \\
(-4.27)\end{array}$ & & $\begin{array}{l}-0.4139^{*} \\
(-2.50)\end{array}$ & $\begin{array}{l}-0.6941^{\cdots} \\
(-3.92)\end{array}$ & $\begin{array}{l}-0.7896^{\circ} \\
(-4.19)\end{array}$ & & $\begin{array}{l}-0.4460^{*} \\
(-2.45)\end{array}$ & $\begin{array}{l}-0.7270 \ldots \\
(-3.79)\end{array}$ & $\begin{array}{l}-0.8199^{\circ *} \\
(-4.12)\end{array}$ & & $\begin{array}{l}-1.1589 \% \\
(-4.16)\end{array}$ & $\begin{array}{l}-1.6180 \ldots \\
(-5.32)\end{array}$ & $\begin{array}{l}-1.7241 \cdots \\
(-5.52)\end{array}$ \\
\hline CEOhold & & $\begin{array}{l}0.7001 \cdots \\
(5.37)\end{array}$ & $\begin{array}{l}0.6797^{\cdots} \\
(5.64)\end{array}$ & $\begin{array}{l}0.7061 \cdots \\
(5.93)\end{array}$ & & $\begin{array}{l}0.2263 \\
(1.04)\end{array}$ & $\begin{array}{l}0.2330 \\
(1.09)\end{array}$ & $\begin{array}{l}0.1862 \\
(0.87)\end{array}$ & & $\begin{array}{l}0.1717 \\
(0.79)\end{array}$ & $\begin{array}{l}0.1917 \\
(0.90)\end{array}$ & $\begin{array}{l}0.1442 \\
(0.67)\end{array}$ & & $\begin{array}{l}0.1233 \\
(0.65)\end{array}$ & $\begin{array}{l}0.2574 \\
(1.36)\end{array}$ & $\begin{array}{l}0.3415^{\circ} \\
(1.81)\end{array}$ & & $\begin{array}{l}-0.4995^{\circ} \\
(-1.67)\end{array}$ & $\begin{array}{l}-0.3284 \\
(-1.11)\end{array}$ & $\begin{array}{l}-0.4437 \\
(-1.50)\end{array}$ \\
\hline Pledge & & $\begin{array}{l}-0.0899^{\cdots} \\
(-7.34)\end{array}$ & $\begin{array}{l}-0.0907 \cdots \\
(-8.09)\end{array}$ & $\begin{array}{l}-0.0836 \cdots \\
(-7.54)\end{array}$ & & $\begin{array}{l}-0.0176 \\
(-0.80)\end{array}$ & $\begin{array}{l}-0.0062 \\
(-0.28)\end{array}$ & $\begin{array}{l}-0.0101 \\
(-0.46)\end{array}$ & & $\begin{array}{l}-0.0159 \\
(-0.72)\end{array}$ & $\begin{array}{l}-0.0046 \\
(-0.21)\end{array}$ & $\begin{array}{l}-0.0085 \\
(-0.39)\end{array}$ & & $\begin{array}{l}-0.0279 \\
(-1.34)\end{array}$ & $\begin{array}{l}-0.0237 \\
(-1.16)\end{array}$ & $\begin{array}{l}-0.0352^{\circ} \\
(-1.73)^{\circ}\end{array}$ & & $\begin{array}{l}0.0432 \\
(1.36)\end{array}$ & $\begin{array}{l}0.0421 \\
(1.34)\end{array}$ & $\begin{array}{l}0.0198 \\
(0.62)\end{array}$ \\
\hline Insthold & & $\begin{array}{l}0.1905^{\prime \prime} \\
(14.9)\end{array}$ & $\begin{array}{l}0.1462^{* \cdots} \\
(12.0)\end{array}$ & $\begin{array}{l}0.1358^{* \prime} \\
(10.7)\end{array}$ & & $\begin{array}{l}0.1927^{* *} \\
(9.47)\end{array}$ & $\begin{array}{l}0.1574 \cdots \\
(7.51)\end{array}$ & $\begin{array}{l}0.1595^{\prime *} \\
(7.59)\end{array}$ & & $\begin{array}{l}0.1917^{\prime \prime} \\
(9.48)\end{array}$ & $\begin{array}{l}0.1579^{\cdots} \\
(7.57)\end{array}$ & $\begin{array}{l}0.1600 \cdots \\
(7.66)\end{array}$ & & $\begin{array}{l}0.1915^{\prime \prime} \\
(10.1)\end{array}$ & $\begin{array}{l}0.1706^{\prime \prime} \\
(8.92)\end{array}$ & $\begin{array}{l}0.1763^{\cdots} \\
(9.07)\end{array}$ & & $\begin{array}{l}0.1979^{\circ \cdots} \\
(7.29)\end{array}$ & $\begin{array}{l}0.1736{ }^{\prime \prime} \\
(6.25)\end{array}$ & $\begin{array}{l}0.1818^{\prime \prime} \\
(6.29)\end{array}$ \\
\hline $\begin{array}{l}\text { Yearly \& Ind. } \\
\text { Dummies }\end{array}$ & NO & NO & NO & $Y E S$ & NO & No & NO & YES & NO & NO & NO & YES & NO & NO & No & YES & No & No & NO & YES \\
\hline Adj. R-square & 0.1973 & 0.0665 & 0.2356 & 0.2863 & 0.0726 & 0.0691 & 0.1224 & 0.1520 & 0.0711 & 0.0693 & 0.1213 & 0.1509 & 0.0735 & 0.0789 & 0.1379 & 0.1748 & 0.0544 & 0.0976 & 0.1495 & 0.1927 \\
\hline Num. of Obs. & 4,711 & 4,714 & 4,710 & 4,710 & 1,177 & 1,178 & 1,177 & 1,177 & 1,176 & 1,177 & 1,176 & 1,176 & 1,177 & 1,178 & 1,177 & 1,177 & 592 & 593 & 592 & 592 \\
\hline
\end{tabular}

Table 9. The effect of the number of independent director on corporate performance-pooled OLS estimation

\begin{tabular}{|c|c|c|c|c|c|c|c|c|c|c|c|c|c|c|c|c|c|c|c|c|}
\hline \multirow{3}{*}{ Variable } & \multirow{2}{*}{\multicolumn{4}{|c|}{ Panel A. Before Matching }} & \multicolumn{16}{|c|}{ Panel B. After-Matching by Four Algorithms } \\
\hline & & & & & \multicolumn{4}{|c|}{ Nearest } & \multicolumn{4}{|c|}{ Caliper } & \multicolumn{4}{|c|}{ Mahala } & \multicolumn{4}{|c|}{ Mahala Caliper } \\
\hline & Model 1 & Model 2 & Model 3 & Model 4 & Model 1 & Model 2 & Model 3 & Model 4 & Model 1 & Model 2 & Model 3 & Model 4 & Model 1 & Model 2 & Model 3 & Model 4 & Model 1 & Model 2 & Model 3 & Model 4 \\
\hline ID_num & $\begin{array}{l}2.1554^{*} \cdot \\
(5.30)\end{array}$ & $\begin{array}{l}2.0068^{\circ} \\
(4.65)\end{array}$ & $\begin{array}{l}2.0386^{\circ} \\
(5.13)\end{array}$ & $\begin{array}{l}1.5872^{\cdots} \\
(3.98)\end{array}$ & $\begin{array}{l}0.0932 \\
(0.21)\end{array}$ & $\begin{array}{l}0.0621 \\
(0.15)\end{array}$ & $\begin{array}{l}0.2191 \\
(0.51)\end{array}$ & $\begin{array}{l}-0.2142 \\
(-0.47)\end{array}$ & $\begin{array}{l}0.1623 \\
(0.37)\end{array}$ & $\begin{array}{l}0.1078 \\
(0.25)\end{array}$ & $\begin{array}{l}0.2852 \\
(0.66)\end{array}$ & $\begin{array}{l}-0.1585 \\
(-0.35)\end{array}$ & $\begin{array}{l}0.2863 \\
(0.70)\end{array}$ & $\begin{array}{l}0.0849 \\
(0.21)\end{array}$ & $\begin{array}{l}0.3633 \\
(0.91)\end{array}$ & $\begin{array}{l}-0.0898 \\
(-0.22)\end{array}$ & $\begin{array}{l}-0.3077 \\
(-0.36)\end{array}$ & $\begin{array}{l}0.2267 \\
(0.27)\end{array}$ & $\begin{array}{l}0.4132 \\
(0.49)\end{array}$ & $\begin{array}{l}-0.6013 \\
(-0.69)\end{array}$ \\
\hline Lnasset & $\begin{array}{l}2.6361^{\cdots} \\
(12.3)\end{array}$ & & $\begin{array}{l}2.2046 \cdots \\
(9.53)\end{array}$ & $\begin{array}{l}2.0765^{\cdots} \\
(8.64)\end{array}$ & $\begin{array}{l}2.1509^{\circ *} \\
(6.11)\end{array}$ & & $\begin{array}{l}1.7019^{\cdots *} \\
(4.37)\end{array}$ & $\begin{array}{l}1.5760 \cdots \\
(3.88)\end{array}$ & $\begin{array}{l}2.0994^{\cdots \cdots} \\
(5.98)\end{array}$ & & $\begin{array}{l}1.6372^{\cdots} \\
(4.23)\end{array}$ & $\begin{array}{l}1.4966^{\circ} \\
(3.70)\end{array}$ & $\begin{array}{l}1.4213 \\
(4.38)\end{array}$ & & $\begin{array}{l}1.0720^{\ldots *} \\
(3.04)\end{array}$ & $\begin{array}{l}0.6748^{\circ} \\
(1.79)\end{array}$ & $\begin{array}{l}1.3300^{\circ *} \\
(2.71)\end{array}$ & & $\begin{array}{l}1.4057^{* *} \\
(2.63)\end{array}$ & $\begin{array}{l}0.9843^{\circ} \\
(1.68)\end{array}$ \\
\hline Debt & $\begin{array}{l}-0.0266 \mathrm{v} \\
(-30.5)\end{array}$ & & $\begin{array}{l}-0.02600^{\cdots} \\
(-30.5)\end{array}$ & $\begin{array}{l}-0.0300 \\
(-31.9)\end{array}$ & $\begin{array}{l}-0.0617^{\cdots} \\
(-7.99)\end{array}$ & & $\begin{array}{l}-0.0585^{* \cdots} \\
(-7.66)\end{array}$ & $\begin{array}{l}-0.0583^{\cdots \cdots} \\
(-7.67)\end{array}$ & $\begin{array}{l}-0.06099^{\cdots} \\
(-7.92)\end{array}$ & & $\begin{array}{l}-0.0577^{*} \\
(-7.59)\end{array}$ & $\begin{array}{l}-0.0574 \cdots \\
(-7.60)\end{array}$ & $\begin{array}{l}-0.0503 \\
(-6.30)\end{array}$ & & $\begin{array}{l}-0.0500^{\cdots *} \\
(-6.44)\end{array}$ & $\begin{array}{l}-0.05088^{\cdots \cdot} \\
(-6.63)\end{array}$ & $\begin{array}{l}-0.0449 \\
(-3.79)\end{array}$ & & $\begin{array}{l}-0.04766^{\cdots} \\
(-4.18)\end{array}$ & $\begin{array}{l}-0.0519^{\cdots} \\
(-4.56)\end{array}$ \\
\hline$R d$ & $\begin{array}{l}-0.5607^{\cdots} \cdot \\
(-8.30)\end{array}$ & & $\begin{array}{l}-0.5003^{\cdots} \cdots \\
(-7.52)\end{array}$ & $\begin{array}{l}-0.5973^{\cdots} \cdots \\
(-8.64)\end{array}$ & $\begin{array}{l}-0.4193^{\cdots} \\
(-3.56)\end{array}$ & & $\begin{array}{l}-0.3174{ }^{\cdots} \\
(-2.73)\end{array}$ & $\begin{array}{l}-0.3532 \cdots \\
(-3.01)\end{array}$ & $\begin{array}{l}-0.4147^{\cdots} \\
(-3.53)\end{array}$ & & $\begin{array}{l}-0.3118^{\circ *} \\
(-2.70)\end{array}$ & $\begin{array}{l}-0.3482 \cdots \\
(-2.99)\end{array}$ & $\begin{array}{l}-0.5454 \\
(-7.02)\end{array}$ & & $\begin{array}{l}-0.4991^{\cdots \cdots} \\
(-6.63)\end{array}$ & $\begin{array}{l}-0.5339 \cdots \\
(-7.02)\end{array}$ & $\begin{array}{l}-0.1321 \\
(-0.93)\end{array}$ & & $\begin{array}{l}-0.0687 \\
(-0.50)\end{array}$ & $\begin{array}{l}-0.1238 \\
(-0.89)\end{array}$ \\
\hline Salesgrowth & $\begin{array}{l}0.0003 \\
(1.42)\end{array}$ & & $\begin{array}{l}0.0004^{\circ} \\
(1.68)\end{array}$ & $\begin{array}{l}0.0004^{*} \\
(1.97)\end{array}$ & $\begin{array}{l}0.0001 \\
(0.32)\end{array}$ & & $\begin{array}{l}0.0001 \\
(0.37)\end{array}$ & $\begin{array}{l}0.0001 \\
(0.45)\end{array}$ & $\begin{array}{l}0.0001 \\
(0.33)\end{array}$ & & $\begin{array}{l}0.0001 \\
(0.38)\end{array}$ & $\begin{array}{l}0.0001 \\
(0.45)\end{array}$ & $\begin{array}{l}0.0022 \\
(2.09)\end{array}$ & & $\begin{array}{l}0.0016 \\
(1.61)\end{array}$ & $\begin{array}{l}0.0026 \cdots \\
(2.59)\end{array}$ & $\begin{array}{l}0.0567 \% \\
(4.71)\end{array}$ & & $\begin{array}{l}0.0497^{\cdots} \\
(4.33)\end{array}$ & $\begin{array}{l}0.0448^{* \cdots} \\
(3.91)\end{array}$ \\
\hline Age & $\begin{array}{l}-0.0321 \\
(-1.40)\end{array}$ & & $\begin{array}{l}0.0277 \\
(1.18)\end{array}$ & $\begin{array}{l}-0.0259 \\
(-0.93)\end{array}$ & $\begin{array}{l}-0.0906 " \\
(-2.18)\end{array}$ & & $\begin{array}{l}-0.0232 \\
(-0.54)\end{array}$ & $\begin{array}{l}0.0115 \\
(0.24)\end{array}$ & $\begin{array}{l}-0.0800^{\circ} \\
(-1.93)\end{array}$ & & $\begin{array}{l}-0.0148 \\
(-0.35)\end{array}$ & $\begin{array}{l}0.0191 \\
(0.39)\end{array}$ & $\begin{array}{l}-0.0356 \\
(-0.90)\end{array}$ & & $\begin{array}{l}0.0129 \\
(0.32)\end{array}$ & $\begin{array}{l}0.0352 \\
(0.77)\end{array}$ & $\begin{array}{l}0.0559 \\
(0.89)\end{array}$ & & $\begin{array}{l}0.1405^{*} \\
(2.22)\end{array}$ & $\begin{array}{l}0.1840^{* *} \\
(2.57)\end{array}$ \\
\hline Board & & $\begin{array}{l}0.0081 \\
(0.08)\end{array}$ & $\begin{array}{l}-0.32877^{\cdots} \\
(-3.50)\end{array}$ & $\begin{array}{l}-0.3173^{\cdots} \cdots \\
(-3.37)\end{array}$ & & $\begin{array}{l}-0.4292^{*} \\
(-2.57)\end{array}$ & $\begin{array}{l}-0.7021{ }^{\cdots \cdots} \\
(-3.92)\end{array}$ & $\begin{array}{l}-0.7838^{\circ \cdots} \\
(-4.09)\end{array}$ & & $\begin{array}{l}-0.4177^{*} \\
(-2.51)\end{array}$ & $\begin{array}{l}-0.6925^{\cdots} \\
(-3.88)\end{array}$ & $\begin{array}{l}-0.7662 \ldots \\
(-4.02)\end{array}$ & & $\begin{array}{l}-0.4493^{*} \\
(-2.45)\end{array}$ & $\begin{array}{l}-0.7343^{\cdots} \cdots \\
(-3.79)\end{array}$ & $\begin{array}{l}-0.8034 \cdots \\
(-4.00)\end{array}$ & & $\begin{array}{l}-1.1959 \cdots \\
(-4.13)\end{array}$ & $\begin{array}{l}-1.6744^{\cdots} \\
(-5.38)\end{array}$ & $\begin{array}{l}-1.6648 \cdots \\
(-5.16)\end{array}$ \\
\hline CEOhold & & $\begin{array}{l}0.7209 \cdots \\
(5.50)\end{array}$ & $\begin{array}{l}0.6944^{\cdots} \\
(5.74)\end{array}$ & $\begin{array}{l}0.7149 \cdots \\
(5.98)\end{array}$ & & $\begin{array}{l}0.2342 \\
(1.08)\end{array}$ & $\begin{array}{l}0.2433 \\
(1.14)\end{array}$ & $\begin{array}{l}0.1827 \\
(0.85)\end{array}$ & & $\begin{array}{l}0.1815 \\
(0.84)\end{array}$ & $\begin{array}{l}0.2041 \\
(0.96)\end{array}$ & $\begin{array}{l}0.1422 \\
(0.66)\end{array}$ & & $\begin{array}{l}0.1248 \\
(0.66)\end{array}$ & $\begin{array}{l}0.2574 \\
(1.35)\end{array}$ & $\begin{array}{l}0.3313^{\circ} \\
(1.75)\end{array}$ & & $\begin{array}{l}-0.4937^{\circ} \\
(-1.65)\end{array}$ & $\begin{array}{l}-0.3149 \\
(-1.05)\end{array}$ & $\begin{array}{l}-0.4635 \\
(-1.56)\end{array}$ \\
\hline Pledge & & $\begin{array}{l}-0.0893^{\cdots} \cdots \\
(-7.25)\end{array}$ & $\begin{array}{l}-0.09000^{\cdots} \\
(-8.00)\end{array}$ & $\begin{array}{l}-0.08277^{\cdots} \\
(-7.44)\end{array}$ & & $\begin{array}{l}-0.0180 \\
(-0.81)\end{array}$ & $\begin{array}{l}-0.0069 \\
(-0.31)\end{array}$ & $\begin{array}{l}-0.0114 \\
(-0.52)\end{array}$ & & $\begin{array}{l}-0.0164 \\
(-0.75)\end{array}$ & $\begin{array}{l}-0.0054 \\
(-0.25)\end{array}$ & $\begin{array}{l}-0.0097 \\
(-0.44)\end{array}$ & & $\begin{array}{l}-0.0280 \\
(-1.35)\end{array}$ & $\begin{array}{l}-0.0236 \\
(-1.15)\end{array}$ & $\begin{array}{l}-0.0353^{\circ} \\
(-1.73)\end{array}$ & & $\begin{array}{l}0.0437 \\
(1,37)\end{array}$ & $\begin{array}{l}0.0424 \\
(1.34)\end{array}$ & $\begin{array}{l}0.0180 \\
(0.56)\end{array}$ \\
\hline Insthold & & $\begin{array}{l}0.1912^{\cdots} \\
(14.9)\end{array}$ & $\begin{array}{l}0.1473^{\cdots} \\
(12.0)\end{array}$ & $\begin{array}{l}0.13711^{\cdots} \\
(10.8)\end{array}$ & & $\begin{array}{l}0.1926 \cdots \\
(9.45)\end{array}$ & $\begin{array}{l}0.1575 \cdots \\
(7.51)\end{array}$ & $\begin{array}{l}0.1596 \cdots \\
(7.60)\end{array}$ & & $\begin{array}{l}0.1916{ }^{\prime \prime} \\
(9.46)\end{array}$ & $\begin{array}{l}0.1580 \cdots \\
(7.57)\end{array}$ & $\begin{array}{l}0.1601 \cdots \\
(7.66)\end{array}$ & & $\begin{array}{l}0.1914^{\prime *} \\
(10.1)\end{array}$ & $\begin{array}{l}0.1704^{\prime *} \\
(8.90)\end{array}$ & $\begin{array}{l}0.1764^{\prime *} \\
(9.08)\end{array}$ & & $\begin{array}{l}0.1961{ }^{\cdots} \\
(7.21)\end{array}$ & $\begin{array}{l}0.1717^{\cdots *} \\
(6.19)\end{array}$ & $\begin{array}{l}0.1837^{\cdots \cdots} \\
(6.33)\end{array}$ \\
\hline $\begin{array}{l}\text { Yearly \& Ind. } \\
\text { Dummies }\end{array}$ & NO & No & No & YES & No & NO & NO & YES & NO & No & No & YES & no & No & No & YES & No & No & no & YES \\
\hline Adj. R-square & 0.1986 & 0.0653 & 0.2377 & 0.2879 & 0.0717 & 0.0690 & 0.1214 & 0.1521 & 0.0700 & 0.0690 & 0.1202 & 0.1508 & 0.0722 & 0.0787 & 0.1366 & 0.1744 & 0.0539 & 0.0970 & 0.1492 & 0.0934 \\
\hline Num. of Obs. & 4,713 & 4,716 & 4,712 & 4,712 & 1,177 & 1,178 & 1,177 & 1,177 & 1,176 & 1,177 & 1,176 & 1,176 & 1,177 & 1,178 & 1,177 & 1,177 & 592 & 593 & 592 & 592 \\
\hline
\end{tabular}


Table 10. The effect of independent director ratio on corporate performance-pooled OLS estimation

\begin{tabular}{|c|c|c|c|c|c|c|c|c|c|c|c|c|c|c|c|c|c|c|c|c|}
\hline \multirow{3}{*}{ Variable } & \multirow{2}{*}{\multicolumn{4}{|c|}{ Panel A. Before Matching }} & \multicolumn{16}{|c|}{ Panel B. After-Matching by Four Algorithms } \\
\hline & & & & & & & arest & & & & tiper & & & $M a$ & hala & & & Mahala & Caliper & \\
\hline & Model 1 & Model 2 & Model 3 & Model 4 & Model 1 & Model 2 & Model 3 & Model 4 & Model 1 & Model 2 & Model 3 & Model 4 & Model 1 & Model 2 & Model 3 & Model 4 & Model 1 & Model 2 & Model 3 & Model 4 \\
\hline$I D \_r$ & $\begin{array}{l}0.1852^{\cdots} \\
(6.79)\end{array}$ & $\begin{array}{l}0.1629^{\cdots} \\
(5.64)\end{array}$ & $\begin{array}{l}0.1720^{\cdots} \\
(6.46)\end{array}$ & $\begin{array}{l}0.1445^{\cdots} \\
(5.40)\end{array}$ & $\begin{array}{l}0.0669^{*} \\
(2.25)\end{array}$ & $\begin{array}{l}0.0373 \\
(1.30)\end{array}$ & $\begin{array}{l}0.0563^{\circ} \\
(1.94)\end{array}$ & $\begin{array}{l}0.0309 \\
(1.02)\end{array}$ & $\begin{array}{l}0.0714^{" \prime} \\
(2.42)\end{array}$ & $\begin{array}{l}0.0410 \\
(1.43)\end{array}$ & $\begin{array}{l}0.0609{ }^{*} \\
(2.11)\end{array}$ & $\begin{array}{l}0.0349 \\
(1.16)\end{array}$ & $\begin{array}{l}0.0716^{\circ} \\
(2.62)\end{array}$ & $\begin{array}{l}0.0379 \\
(1.40)\end{array}$ & $\begin{array}{l}0.0590^{*} \\
(2.22)\end{array}$ & $\begin{array}{l}0.0306 \\
(1.10)\end{array}$ & $\begin{array}{l}0.1699 \cdots \\
(3.01)\end{array}$ & $\begin{array}{l}0.0597 \\
(1.02)\end{array}$ & $\begin{array}{l}0.0626 \\
(1.09)\end{array}$ & $\begin{array}{l}-0.0076 \\
(-0.13)\end{array}$ \\
\hline Lnasset & $\begin{array}{l}2.6730^{\cdots} \\
(12.6)\end{array}$ & & $\begin{array}{l}2.2422 \cdots \\
(9.74)\end{array}$ & $\begin{array}{l}2.1187 \cdots \\
(8.84)\end{array}$ & $\begin{array}{l}2.1712 \cdots \\
(6.20)\end{array}$ & & $\begin{array}{l}1.7146^{\circ} \\
(4.42)\end{array}$ & $\begin{array}{l}1.5874 \cdots \\
(3.91)\end{array}$ & $\begin{array}{l}2.1247 \\
(6.10)\end{array}$ & & $\begin{array}{l}1.6513^{\cdots \cdots} \\
(4.27)\end{array}$ & $\begin{array}{l}1.5088^{\cdots} \\
(3.73)\end{array}$ & $\begin{array}{l}1.4646^{\circ} \\
(4.53)\end{array}$ & & $\begin{array}{l}1.0891^{\cdots} \\
(3.09)\end{array}$ & $\begin{array}{l}0.7019^{\circ} \\
(1.86)\end{array}$ & $\begin{array}{l}1.3439 \cdots \\
(2.85)\end{array}$ & & $\begin{array}{l}1.3770 \% \\
(2.58)\end{array}$ & $\begin{array}{l}0.9862^{\circ} \\
(1.68)\end{array}$ \\
\hline Debt & $\begin{array}{l}-0.0262 \cdots \\
(-30.0)\end{array}$ & & $\begin{array}{l}-0.0256{ }^{\circ} \\
(-30.0)\end{array}$ & $\begin{array}{l}-0.0297 \cdots \\
(-31.5)\end{array}$ & $\begin{array}{l}-0.06222^{\cdots} \\
(-8.08)\end{array}$ & & $\begin{array}{l}-0.05900^{\cdots} \\
(-7.74)\end{array}$ & $\begin{array}{l}-0.0588^{* \cdots} \\
(-7.75)\end{array}$ & $\begin{array}{l}-0.0614 \\
(-8.01)\end{array}$ & & $\begin{array}{l}-0.0588^{\cdots} \\
(-7.67)\end{array}$ & $\begin{array}{l}-0.05800^{\prime \prime} \\
(-7.67)\end{array}$ & $\begin{array}{l}-0.0512 \cdots \\
(-6.42)\end{array}$ & & $\begin{array}{l}-0.0505^{\prime \cdots} \\
(-6.52)\end{array}$ & $\begin{array}{l}-0.0511^{3} \cdots \\
(-6.70)\end{array}$ & $\begin{array}{l}-0.0462^{2 *} \\
(-3.92)\end{array}$ & & $\begin{array}{l}-0.0476 \cdots \\
(-4.18)\end{array}$ & $\begin{array}{l}-0.0520 " \\
(-4.57)\end{array}$ \\
\hline Rd & $\begin{array}{l}-0.5750 \cdots \\
(-8.54)\end{array}$ & & $\begin{array}{l}-0.5144^{\cdots \cdots} \\
(-7.76)\end{array}$ & $\begin{array}{l}-0.6016 \cdots \\
(-8.73)\end{array}$ & $\begin{array}{l}-0.4419^{\cdots} \\
(-3.75)\end{array}$ & & $\begin{array}{l}-0.3352^{\cdots *} \\
(-2.89)\end{array}$ & $\begin{array}{l}-0.3628^{\cdots} \\
(-3.09)\end{array}$ & $\begin{array}{l}-0.4374 \\
(-3.73)\end{array}$ & & $\begin{array}{l}-0.3298^{\cdots *} \\
(-2.86)\end{array}$ & $\begin{array}{l}-0.3580^{\cdots} \\
(-3.07)\end{array}$ & $\begin{array}{l}-0.5485^{\cdots} \\
(-7.08)\end{array}$ & & $\begin{array}{l}-0.5015^{\cdots \cdots} \\
(-6.67)\end{array}$ & $\begin{array}{l}-0.5340^{\cdots} \\
(-7.03)\end{array}$ & $\begin{array}{l}-0.0928 \\
(-0.66)\end{array}$ & & $\begin{array}{l}-0.0625 \\
(-0.46)\end{array}$ & $\begin{array}{l}-0.1124 \\
(-0.81)\end{array}$ \\
\hline Salesgrowth & $\begin{array}{l}0.0003 \\
(1.43)\end{array}$ & & $\begin{array}{l}0.0004^{*} \\
(1.68)\end{array}$ & $\begin{array}{l}0.0004^{\circ} \\
(1.95)\end{array}$ & $\begin{array}{l}0.0001 \\
(0.37)\end{array}$ & & $\begin{array}{l}0.0001 \\
(0.40)\end{array}$ & $\begin{array}{l}0.0001 \\
(0.48)\end{array}$ & $\begin{array}{l}0.0001 \\
(0.38)\end{array}$ & & $\begin{array}{l}0.0001 \\
(0.41)\end{array}$ & $\begin{array}{l}0.0001 \\
(0.48)\end{array}$ & $\begin{array}{l}0.0022{ }^{\circ} \\
(2.13)\end{array}$ & & $\begin{array}{l}0.0016^{\circ} \\
(1.65)\end{array}$ & $\begin{array}{l}0.0026^{\cdots *} \\
(2.61)\end{array}$ & $\begin{array}{l}0.0574^{\cdots} \\
(4.82)\end{array}$ & & $\begin{array}{l}0.0499^{\circ *} \\
(4.36)\end{array}$ & $\begin{array}{l}0.0450^{* \cdots} \\
(3.92)\end{array}$ \\
\hline Age & $\begin{array}{l}-0.0288 \\
(-1.26)\end{array}$ & & $\begin{array}{l}0.0295 \\
(1.26)\end{array}$ & $\begin{array}{l}-0.0248 \\
(-0.89)\end{array}$ & $\begin{array}{l}-0.0708^{\circ} \\
(-1.70)\end{array}$ & & $\begin{array}{l}-0.0112 \\
(-0.26)\end{array}$ & $\begin{array}{l}0.0234 \\
(0.48)\end{array}$ & $\begin{array}{l}-0.0599 \\
(-1.44)\end{array}$ & & $\begin{array}{l}-0.0028 \\
(-0.07)\end{array}$ & $\begin{array}{l}0.0310 \\
(0.64)\end{array}$ & $\begin{array}{l}-0.0216 \\
(-0.54)\end{array}$ & & $\begin{array}{l}0.0210 \\
(0.52)\end{array}$ & $\begin{array}{l}0.0453 \\
(0.99)\end{array}$ & $\begin{array}{l}0.0831 \\
(1.32)\end{array}$ & & $\begin{array}{l}0.1417^{* *} \\
(2.24)\end{array}$ & $\begin{array}{l}0.1889^{\ldots} \\
(2.64)\end{array}$ \\
\hline Board & & $\begin{array}{l}0.0124 \\
(0.13)\end{array}$ & $\begin{array}{l}-0.3175 \% \\
(-3.40)\end{array}$ & $\begin{array}{l}-0.3139 \cdots \\
(-3.35)\end{array}$ & & $\begin{array}{l}-0.4055^{\prime \prime} \\
(-2.42)\end{array}$ & $\begin{array}{l}-0.67900^{\cdots} \\
(-3.83)\end{array}$ & $\begin{array}{l}-0.7989 \cdots \\
(-4.25)\end{array}$ & & $\begin{array}{l}-0.3902^{\prime \prime} \\
(-2.35)\end{array}$ & $\begin{array}{l}-0.6644 " \cdots \\
(-3.77)\end{array}$ & $\begin{array}{l}-0.7764= \\
(-4.15)\end{array}$ & & $\begin{array}{l}-0.4187^{\prime \prime} \\
(-2.29)\end{array}$ & $\begin{array}{l}-0.6856 \cdots \\
(-3.58)\end{array}$ & $\begin{array}{l}-0.79822^{\prime \prime} \\
(-4.02)\end{array}$ & & $\begin{array}{l}-1.0729 \cdots \\
(-3.64)\end{array}$ & $\begin{array}{l}-1.5229 \cdots \\
(-4.75)\end{array}$ & $\begin{array}{l}-1.7365^{*} \\
(-5.25)\end{array}$ \\
\hline CEOhold & & $\begin{array}{l}0.7097^{\cdots} \\
(5.45)\end{array}$ & $\begin{array}{l}0.6903^{\cdots} \\
(5.73)\end{array}$ & $\begin{array}{l}0.7157^{\cdots} \\
(6.01)\end{array}$ & & $\begin{array}{l}0.2211 \\
(1.02)\end{array}$ & $\begin{array}{l}0.2444 \\
(1.14)\end{array}$ & $\begin{array}{l}0.1924 \\
(0.89)\end{array}$ & & $\begin{array}{l}0.1677 \\
(0.78)\end{array}$ & $\begin{array}{l}0.2043 \\
(0.96)\end{array}$ & $\begin{array}{l}0.1511 \\
(0.71)\end{array}$ & & $\begin{array}{l}0.1287 \\
(0.68)\end{array}$ & $\begin{array}{l}0.2713 \\
(1.43)\end{array}$ & $\begin{array}{l}0.3479^{\circ} \\
(1.84)\end{array}$ & & $\begin{array}{l}-0.4727 \\
(-1.58)\end{array}$ & $\begin{array}{l}-0.2975 \\
(-1.00)\end{array}$ & $\begin{array}{l}-0.4464 \\
(-1.50)\end{array}$ \\
\hline Pledge & & $\begin{array}{l}-0.0895^{\cdots} \\
(-7.31)\end{array}$ & $\begin{array}{l}-0.0903^{\cdots \cdots} \\
(-8.05)\end{array}$ & $\begin{array}{l}-0.0834^{\cdots} \\
(-7.52)\end{array}$ & & $\begin{array}{l}-0.0162 \\
(-0.73)\end{array}$ & $\begin{array}{l}-0.0048 \\
(-0.22)\end{array}$ & $\begin{array}{l}-0.0090 \\
(-0.41)\end{array}$ & & $\begin{array}{l}-0.0144 \\
(-0.66)\end{array}$ & $\begin{array}{l}-0.0032 \\
(-0.15)\end{array}$ & $\begin{array}{l}-0.0073 \\
(-0.33)\end{array}$ & & $\begin{array}{l}-0.0273 \\
(-1.31)\end{array}$ & $\begin{array}{l}-0.0230 \\
(-1.13)\end{array}$ & $\begin{array}{l}-0.0349^{\circ} \\
(-1.71)\end{array}$ & & $\begin{array}{l}0.0438 \\
(1.38)\end{array}$ & $\begin{array}{l}0.0423 \\
(1.34)\end{array}$ & $\begin{array}{l}0.0197 \\
(0.62)\end{array}$ \\
\hline Insthold & & $\begin{array}{l}0.1896^{\cdots} \\
(14.8)\end{array}$ & $\begin{array}{l}0.1455^{\cdots} \\
(11.9)\end{array}$ & $\begin{array}{l}0.1351 \cdots \\
(10.7)\end{array}$ & & $\begin{array}{l}0.1918^{\cdots \cdots} \\
(9.42)\end{array}$ & $\begin{array}{l}0.1565^{\cdots} \\
(7.47)\end{array}$ & $\begin{array}{l}0.1590 \cdots \\
(7.57)\end{array}$ & & $\begin{array}{l}0.1908^{\cdots *} \\
(9.43)\end{array}$ & $\begin{array}{l}0.1569^{\cdots} \\
(7.53)\end{array}$ & $\begin{array}{l}0.1595^{\cdots} \\
(7.63)\end{array}$ & & $\begin{array}{l}0.1905^{\circ \cdots} \\
(10.0)\end{array}$ & $\begin{array}{l}0.1695^{\cdots} \\
(8.86)\end{array}$ & $\begin{array}{l}0.1756^{\cdots} \\
(9.04)\end{array}$ & & $\begin{array}{l}0.1941^{\cdots} \\
(7.14)\end{array}$ & $\begin{array}{l}0.1706^{\circ} \\
(6.16)\end{array}$ & $\begin{array}{l}0.1822^{\prime \prime} \\
(6.27)\end{array}$ \\
\hline $\begin{array}{l}\text { Yearly \& Ind. } \\
\text { Dummies }\end{array}$ & No & No & NO & YES & NO & No & No & YES & NO & NO & NO & YES & No & NO & NO & YES & NO & No & NO & YES \\
\hline $\begin{array}{l}\text { Adj. R-square } \\
\text { Num. of Obs. }\end{array}$ & $\begin{array}{l}0.1979 \\
4,711\end{array}$ & $\begin{array}{l}0.0671 \\
4,714\end{array}$ & $\begin{array}{l}0.2368 \\
4,710\end{array}$ & $\begin{array}{l}0.2863 \\
4,710\end{array}$ & $\begin{array}{l}0.0757 \\
1.177\end{array}$ & $\begin{array}{l}0.0703 \\
1,178\end{array}$ & $\begin{array}{l}0.1241 \\
1,177\end{array}$ & $\begin{array}{l}0.1527 \\
1,177\end{array}$ & $\begin{array}{l}0.0745 \\
1,176\end{array}$ & $\begin{array}{l}0.0706 \\
1,177\end{array}$ & $\begin{array}{l}0.1232 \\
1,176\end{array}$ & $\begin{array}{l}0.1517 \\
1,176\end{array}$ & $\begin{array}{l}0.0722 \\
1,177\end{array}$ & $\begin{array}{l}0.0802 \\
1,178\end{array}$ & $\begin{array}{l}0.1396 \\
1,177\end{array}$ & $\begin{array}{l}0.1752 \\
1,177\end{array}$ & $\begin{array}{l}0.0681 \\
592\end{array}$ & $\begin{array}{l}0.0985 \\
593\end{array}$ & $\begin{array}{l}0.1506 \\
592\end{array}$ & $\begin{array}{l}0.1928 \\
592\end{array}$ \\
\hline
\end{tabular}

Table 11. The effect of board independence on executive compensation-pooled OLS estimation

\begin{tabular}{|c|c|c|c|c|c|c|c|c|c|}
\hline \multirow{2}{*}{ Variable } & \multicolumn{9}{|c|}{ Panel A. Before Matching } \\
\hline & & \multicolumn{2}{|l|}{ ExecuPayT } & \multicolumn{3}{|c|}{ ExecuPayA } & \multicolumn{3}{|c|}{ ExecuPayR } \\
\hline \multirow{2}{*}{$I D \_d$} & $17196^{* * *}$ & & & $934.71^{* * *}$ & & & 0.3254 & & \\
\hline & $(6.20)$ & & & $(3.74)$ & & & $(0.06)$ & & \\
\hline \multirow{2}{*}{ ID_num } & & $12286^{* * *}$ & & & $800.80^{* * *}$ & & & 0.2706 & \\
\hline & & $(8.81)$ & & & $(6.36)$ & & & $(0.09)$ & \\
\hline \multirow{2}{*}{$I D \_r$} & & & $648.17^{* * *}$ & & & $36.959^{* * *}$ & & & 0.0125 \\
\hline & & & $(6.89)$ & & & $(4.36)$ & & & $(0.07)$ \\
\hline \multirow{2}{*}{ Lnasset } & $16829^{* * *}$ & $16508^{* * *}$ & $16856^{* * *}$ & $1322.1^{* * *}$ & $1298.1^{* * *}$ & $1322.9^{* * *}$ & $-3.9445^{* *}$ & $-3.9502^{* *}$ & $-3.9422^{* *}$ \\
\hline & $(18.8)$ & $(18.5)$ & $(18.8)$ & (16.4) & $(16.1)$ & $(16.4)$ & $(-2.01)$ & $(-2.01)$ & $(-2.01)$ \\
\hline \multirow{2}{*}{ Debt } & $-12.144^{* * *}$ & $-12.139^{* * *}$ & $-12.231^{* * *}$ & $-1.6106^{* * *}$ & $-1.6032^{* * *}$ & $-1.6138^{* * *}$ & $-0.0518^{* * *}$ & $-0.0519^{* * *}$ & $-0.0519^{* * 1}$ \\
\hline & $(-2.94)$ & $(-2.96)$ & $(-2.97)$ & $(-4.33)$ & $(-4.33)$ & $(-4.35)$ & $(-2.39)$ & $(-2.39)$ & $(-2.39)$ \\
\hline \multirow{2}{*}{ CDdummy } & 277.52 & 266.44 & 136.45 & $578.19^{* * *}$ & $576.28^{* * *}$ & $569.85^{* * * *}$ & $-38.141^{* * *}$ & $-38.149^{* * *}$ & $-38.148^{* * *}$ \\
\hline & $(0.12)$ & $(0.11)$ & $(0.06)$ & $(2.67)$ & $(2.68)$ & $(2.64)$ & $(-6.96)$ & $(-6.96)$ & $(-6.96)$ \\
\hline \multirow{2}{*}{ Profit } & 55.776 & 51.978 & 51.797 & $26.059^{* * *}$ & $25.639^{* * *}$ & $25.790^{* * *}$ & $-0.6744^{* * *}$ & $-0.6749^{* * *}$ & $-0.6747^{* * *}$ \\
\hline & $(0.90)$ & $(0.85)$ & $(0.84)$ & (4.69) & $(4.64)$ & $(4.65)$ & $(-3.53)$ & $(-3.53)$ & $(-3.52)$ \\
\hline \multirow{2}{*}{ MTB } & $8070.0^{* * *}$ & $8031.9^{* * *}$ & $8025.9^{* * *}$ & $1100.1^{* * *}$ & $1093.8^{* * *}$ & $1096.7^{* * *}$ & -0.7247 & -0.7245 & -0.7252 \\
\hline & (7.98) & $(8.00)$ & (7.95) & (12.1) & $(12.1)$ & (12.1) & $(-0.31)$ & $(-0.31)$ & $(-0.31)$ \\
\hline \multirow{2}{*}{ StockRet } & -847.89 & -947.78 & -815.23 & 101.71 & 96.064 & 103.78 & 3.2581 & 3.2572 & 3.2601 \\
\hline & $(-0.63)$ & $(-0.71)$ & $(-0.61)$ & $(0.84)$ & $(0.80)$ & $(0.86)$ & (1.13) & (1.13) & (1.13) \\
\hline \multirow{2}{*}{ Board } & $-1105.0^{* * *}$ & $-1199.4^{* * *}$ & $-985.63^{* *}$ & -4.8280 & -10.881 & 2.0027 & -0.3538 & -0.3554 & -0.3511 \\
\hline & $(-2.86)$ & $(-3.13)$ & $(-2.56)$ & $(-0.14)$ & $(-0.31)$ & $(0.06)$ & $(-0.45)$ & $(-0.45)$ & $(-0.45)$ \\
\hline \multirow{2}{*}{ CEOhold } & $1756.1^{* * *}$ & $1771.0^{* * *}$ & $1795.9^{* * *}$ & $81.422^{*}$ & $81.012^{*}$ & $83.351^{* *}$ & 1.1881 & 1.1884 & 1.1893 \\
\hline & $(3.73)$ & (3.79) & $(3.82)$ & (1.92) & $(1.92)$ & (1.97) & $(1.20)$ & $(1.20)$ & $(1.20)$ \\
\hline \multirow{2}{*}{ Insthold } & 29.867 & 30.049 & 25.128 & -0.9191 & -0.7088 & -1.1405 & 0.0432 & 0.0432 & 0.0431 \\
\hline & $(0.61)$ & $(0.61)$ & $(0.51)$ & $(-0.21)$ & $(-0.16)$ & $(-0.26)$ & $(0.42)$ & $(0.42)$ & $(0.42)$ \\
\hline Yearly \& Ind. Dummies & YES & YES & $Y E S$ & YES & YES & $Y E S$ & YES & YES & $Y E S$ \\
\hline Adj. R-square & 0.1715 & 0.1843 & 0.1741 & 0.2016 & 0.2087 & 0.2029 & 0.0382 & 0.0382 & 0.0382 \\
\hline Num. of Obs. & 2,943 & 2,943 & 2,943 & 2,943 & 2,943 & 2,943 & 2,317 & 2,317 & 2,317 \\
\hline
\end{tabular}




\begin{tabular}{|c|c|c|c|c|c|c|c|c|c|}
\hline \multirow{2}{*}{ Variable } & \multicolumn{9}{|c|}{ Panel B. Matching Algorithm: Nearest } \\
\hline & \multicolumn{3}{|c|}{ ExecuPayT } & \multicolumn{3}{|c|}{ ExecuPayA } & \multicolumn{3}{|c|}{ ExecuPayR } \\
\hline & $14547^{* *}$ & & & -206.97 & & & 3.0478 & & \\
\hline$-a$ & $(2.35)$ & & & $(-0.31)$ & & & $(0.95)$ & & \\
\hline ID_num & & $\begin{array}{l}11368^{* * * *} \\
(3.82)\end{array}$ & & & $\begin{array}{l}444.36 \\
(1.38)\end{array}$ & & & $\begin{array}{l}1.0081 \\
(0.64)\end{array}$ & \\
\hline$I D \_r$ & & & $\begin{array}{l}580.10^{* * *} \\
(2.94)\end{array}$ & & & $\begin{array}{l}5.5631 \\
(0.26)\end{array}$ & & & $\begin{array}{l}0.0863 \\
(0.83)\end{array}$ \\
\hline Lnasset & $\begin{array}{l}33861^{* * *} \\
(11.1)\end{array}$ & $\begin{array}{l}33153^{* * *} \\
(10.9)\end{array}$ & $\begin{array}{l}33839^{* * * *} \\
(11.1)\end{array}$ & $\begin{array}{l}1846.5^{* * *} \\
(5.82)\end{array}$ & $\begin{array}{l}1799.0^{* * * *} \\
(5.65)\end{array}$ & $\begin{array}{l}1839.2^{* * *} \\
(5.80)\end{array}$ & $\begin{array}{l}-0.7994 \\
(-0.51)\end{array}$ & $\begin{array}{l}-0.8130 \\
(-0.52)\end{array}$ & $\begin{array}{l}-0.7485 \\
(-0.48)\end{array}$ \\
\hline Debt & $\begin{array}{l}-94.953^{*} \\
(-1.74)\end{array}$ & $\begin{array}{l}-103.00^{*} \\
(-1.89)\end{array}$ & $\begin{array}{l}-101.16^{*} \\
(-1.85)\end{array}$ & $\begin{array}{l}-15.745^{* * *} \\
(-2.58)\end{array}$ & $\begin{array}{l}-16.245^{* * *} \\
(-2.66)\end{array}$ & $\begin{array}{l}-15.893^{\text {*** }} \\
(-2.60)\end{array}$ & $\begin{array}{l}-0.0261 \\
(-0.79)\end{array}$ & $\begin{array}{l}-0.0256 \\
(-0.78)\end{array}$ & $\begin{array}{l}-0.0266 \\
(-0.81)\end{array}$ \\
\hline CDdummy & $\begin{array}{l}-3766.0 \\
(-0.44)\end{array}$ & $\begin{array}{l}-4054.0 \\
(-0.48)\end{array}$ & $\begin{array}{l}-4376.5 \\
(-0.52)\end{array}$ & $\begin{array}{l}-1125.4 \\
(-1.24)\end{array}$ & $\begin{array}{l}-1164.3 \\
(-1.28)\end{array}$ & $\begin{array}{l}-1141.8 \\
(-1.25)\end{array}$ & $\begin{array}{l}-18.384^{* * *} \\
(-4.00)\end{array}$ & $\begin{array}{l}-18.205^{* * *} \\
(-3.96)\end{array}$ & $\begin{array}{l}-18.400^{* * *} \\
(-3.99)\end{array}$ \\
\hline Profit & $\begin{array}{l}-181.04 \\
(-0.64)\end{array}$ & $\begin{array}{l}-179.66 \\
(-0.64)\end{array}$ & $\begin{array}{l}-194.83 \\
(-0.69)\end{array}$ & $\begin{array}{l}86.150^{* *} \\
(2.51)\end{array}$ & $\begin{array}{l}90.023^{* * *} \\
(2.62)\end{array}$ & $\begin{array}{l}87.438^{* *} \\
(2.55)\end{array}$ & $\begin{array}{l}-0.7486^{* * *} \\
(-3.64)\end{array}$ & $\begin{array}{l}-0.7562^{* * *} \\
(-3.68)\end{array}$ & $\begin{array}{l}-0.7562^{* * *} \\
(-3.68)\end{array}$ \\
\hline MTB & $\begin{array}{l}17774^{* * *} \\
(4.49)\end{array}$ & $\begin{array}{l}17740^{* * *} \\
(4.52)\end{array}$ & $\begin{array}{l}17737^{* * *} \\
(4.50)\end{array}$ & $\begin{array}{l}1707.5^{* * *} \\
(3.79)\end{array}$ & $\begin{array}{l}1675.0^{* * *} \\
(3.72)\end{array}$ & $\begin{array}{l}1693.4^{* * *} \\
(3.76)\end{array}$ & $\begin{array}{l}0.9277 \\
(0.41)\end{array}$ & $\begin{array}{l}0.9821 \\
(0.44)\end{array}$ & $\begin{array}{l}0.9436 \\
(0.42)\end{array}$ \\
\hline StockRet & $\begin{array}{l}-10931^{* *} \\
(-2.38)\end{array}$ & $\begin{array}{l}-11198^{* *} \\
(-2.45)\end{array}$ & $\begin{array}{l}-10720^{* *} \\
(-2.34)\end{array}$ & $\begin{array}{l}-212.60 \\
(-0.43)\end{array}$ & $\begin{array}{l}-119.95 \\
(-0.25)\end{array}$ & $\begin{array}{l}-174.35 \\
(-0.36)\end{array}$ & $\begin{array}{l}-1.3312 \\
(-0.56)\end{array}$ & $\begin{array}{l}-1.4458 \\
(-0.61)\end{array}$ & $\begin{array}{l}-1.3773 \\
(-0.58)\end{array}$ \\
\hline Board & $\begin{array}{l}-2031.7 \\
(-1.35)\end{array}$ & $\begin{array}{l}-2596.9^{*} \\
(-1.72)\end{array}$ & $\begin{array}{l}-1529.2 \\
(-1.02)\end{array}$ & $\begin{array}{l}35.489 \\
(0.25)\end{array}$ & $\begin{array}{l}21.511 \\
(0.15)\end{array}$ & $\begin{array}{l}38.734 \\
(0.27)\end{array}$ & $\begin{array}{l}-0.1563 \\
(-0.24)\end{array}$ & $\begin{array}{l}-0.1833 \\
(-0.28)\end{array}$ & $\begin{array}{l}-0.0943 \\
(-0.14)\end{array}$ \\
\hline CEOhold & $\begin{array}{l}-73.234 \\
(-0.04)\end{array}$ & $\begin{array}{l}-6.4136 \\
(0.00)\end{array}$ & $\begin{array}{l}111.14 \\
(0.06)\end{array}$ & $\begin{array}{l}-386.38^{* *} \\
(-2.16)\end{array}$ & $\begin{array}{l}-391.55^{* *} \\
(-2.19)\end{array}$ & $\begin{array}{l}-389.97^{* *} \\
(-2.18)\end{array}$ & $\begin{array}{l}2.1887^{* *} \\
(2.45)\end{array}$ & $\begin{array}{l}2.2416^{* *} \\
(2.52)\end{array}$ & $\begin{array}{l}2.2446^{* *} \\
(2.52)\end{array}$ \\
\hline Insthold & $\begin{array}{l}-16.468 \\
(-0.10)\end{array}$ & $\begin{array}{l}-35.432 \\
(-0.21)\end{array}$ & $\begin{array}{l}-31.528 \\
(-0.19)\end{array}$ & $\begin{array}{l}-19.424 \\
(-1.05)\end{array}$ & $\begin{array}{l}-19.818 \\
(-1.08)\end{array}$ & $\begin{array}{l}-19.425 \\
(-1.05)\end{array}$ & $\begin{array}{l}0.0260 \\
(0.29)\end{array}$ & $\begin{array}{l}0.0256 \\
(0.28)\end{array}$ & $\begin{array}{l}0.0240 \\
(0.26)\end{array}$ \\
\hline Yearly \& Ind. Dummies & $Y E S$ & $Y E S$ & $Y E S$ & YES & $Y E S$ & $Y E S$ & YES & $Y E S$ & $Y E S$ \\
\hline Adj. R-square & 0.2113 & 0.2207 & 0.2146 & 0.1022 & 0.1043 & 0.1021 & 0.0716 & 0.0708 & 0.0713 \\
\hline Num. of Obs. & 764 & 764 & 764 & 784 & 784 & 784 & 644 & 644 & 644 \\
\hline
\end{tabular}

Note. This table reports the pooled OLS estimation results of the effect of board independence on executive compensation. Board independence is proxied by $I D \_d, I D \_n u m$ and $I D \_r$. Executive compensation is proxied by ExecuPayT, ExecuPayA and ExecuPayR. Panel $\mathrm{A}$ is estimation result under before-matching samples. Panel B, C and D reports estimation results under after-matching samples through Nearest, Caliper and Mahala matching. Constant terms are omitted. The $t$-statistics are presented in parentheses. ${ }^{* * *},{ }^{* *}$ and ${ }^{*}$ denote estimated coefficient reaches statistical significance at the $1 \%, 5 \%$ and $10 \%$ levels, respectively.

Table 11. The effect of board independence on executive compensation-pooled OLS estimation (continued)

\begin{tabular}{|c|c|c|c|c|c|c|c|c|c|}
\hline \multirow{2}{*}{ Variable } & \multicolumn{9}{|c|}{ Panel C. Matching Algorithm: Caliper } \\
\hline & \multicolumn{3}{|c|}{ ExecuPayT } & \multicolumn{3}{|c|}{ ExecuPayA } & \multicolumn{3}{|c|}{ ExecuPayR } \\
\hline \multirow{2}{*}{ ID_d } & $14547 * *$ & & & -240.77 & & & 3.1259 & & \\
\hline & $(2.35)$ & & & $(-0.36)$ & & & $(0.97)$ & & \\
\hline \multirow{2}{*}{ ID_num } & & $11368^{* * *}$ & & & 432.01 & & & 1.0410 & \\
\hline & & $(3.82)$ & & & $(1.34)$ & & & $(0.66)$ & \\
\hline \multirow{2}{*}{ ID_r } & & & $580.10^{* * *}$ & & & 4.4973 & & & 0.0888 \\
\hline & & & $(2.94)$ & & & $(0.21)$ & & & $(0.86)$ \\
\hline \multirow{2}{*}{ Lnasset } & $33861 * * *$ & $33153^{* * *}$ & $33839 * * *$ & $1873.5^{* * *}$ & $1825.6^{* * *}$ & $1865.7^{* * *}$ & -0.8637 & -0.8765 & -0.8111 \\
\hline & (11.1) & $(10.9)$ & $(11.1)$ & $(6.00)$ & $(5.73)$ & $(5.88)$ & $(-0.55)$ & $(-0.56)$ & $(-0.52)$ \\
\hline \multirow{2}{*}{ Debt } & $-94.953^{*}$ & $-103.00^{*}$ & $-101.16^{*}$ & $-16.015 * * *$ & $-16.503 * * *$ & $-16.150 * * *$ & -0.0252 & -0.0248 & -0.0258 \\
\hline & $(-1.74)$ & $(-1.89)$ & $(-1.85)$ & $(-2.62)$ & $(-2.70)$ & $(-2.64)$ & $(-0.77)$ & $(-0.75)$ & $(-0.78)$ \\
\hline \multirow{2}{*}{ CDdummy } & -3766.0 & -4054.0 & -4376.5 & -1223.3 & -1259.4 & -1237.5 & $-18.224 * * *$ & $-18.048 * * *$ & $-18.244 * * *$ \\
\hline & $(-0.44)$ & $(-0.48)$ & $(-0.52)$ & $(-1.34)$ & $(-1.38)$ & $(-1.36)$ & $(-3.96)$ & $(-3.92)$ & $(-3.95)$ \\
\hline \multirow{2}{*}{ Profit } & -181.04 & -179.66 & -194.83 & $92.647 * * *$ & $96.382 * * *$ & $93.908^{* * *}$ & $-0.7692 * * *$ & $-0.7765 * * *$ & $-0.7769 * * *$ \\
\hline & $(-0.64)$ & $(-0.64)$ & $(-0.69)$ & $(2.68)$ & $(2.79)$ & $(2.72)$ & $(-3.69)$ & $(-3.72)$ & $(-3.73)$ \\
\hline \multirow{2}{*}{ MTB } & $17774 * * *$ & $17740 * * *$ & $17737 * * *$ & $1765.8 * * *$ & $1731.1^{* * *}$ & $1751.0^{* * *}$ & 0.8771 & 0.9347 & 0.8939 \\
\hline & (4.49) & (4.52) & $(4.50)$ & (3.91) & $(3.84)$ & $(3.88)$ & $(0.39)$ & $(0.41)$ & $(0.40)$ \\
\hline \multirow{2}{*}{ StockRet } & $-10931^{* *}$ & $-11198 * *$ & $-10720^{* *}$ & -185.99 & -92.592 & -147.64 & -1.3793 & -1.4948 & -1.4256 \\
\hline & $(-2.38)$ & $(-2.45)$ & $(-2.34)$ & $(-0.38)$ & $(-0.19)$ & $(-0.30)$ & $(-0.58)$ & $(-0.63)$ & $(-0.60)$ \\
\hline
\end{tabular}




\begin{tabular}{|c|c|c|c|c|c|c|c|c|c|}
\hline Board & $\begin{array}{c}-2031.7 \\
(-1.35)\end{array}$ & $\begin{array}{c}-2596.9^{*} \\
(-1.72)\end{array}$ & $\begin{array}{l}-1529.2 \\
(-1.02)\end{array}$ & $\begin{array}{c}35.198 \\
(0.25)\end{array}$ & $\begin{array}{c}21.564 \\
(0.15)\end{array}$ & $\begin{array}{c}37.726 \\
(0.27)\end{array}$ & $\begin{array}{c}-0.1551 \\
(-0.24)\end{array}$ & $\begin{array}{l}-0.1830 \\
(-0.28)\end{array}$ & $\begin{array}{c}-0.0914 \\
(-0.14)\end{array}$ \\
\hline CEOhold & $\begin{array}{c}-73.234 \\
(-0.04)\end{array}$ & $\begin{array}{c}-6.4136 \\
(0.00)\end{array}$ & $\begin{array}{c}111.14 \\
(0.06)\end{array}$ & $\begin{array}{c}-369.40 * * \\
(-2.06)\end{array}$ & $\begin{array}{c}-375.50 * * \\
(-2.10)\end{array}$ & $\begin{array}{c}-373.61 * * \\
(-2.09)\end{array}$ & $\begin{array}{c}2.1494 * * \\
(2.40)\end{array}$ & $\begin{array}{c}2.2047 * * \\
(2.47)\end{array}$ & $\begin{array}{c}2.2070 * * \\
(2.47)\end{array}$ \\
\hline Insthold & $\begin{array}{c}-16.468 \\
(-0.10)\end{array}$ & $\begin{array}{c}-35.432 \\
(-0.21)\end{array}$ & $\begin{array}{c}-31.528 \\
(-0.19)\end{array}$ & $\begin{array}{l}-21.057 \\
(-1.14)\end{array}$ & $\begin{array}{c}-21.377 \\
(-1.16)\end{array}$ & $\begin{array}{c}-21.006 \\
(-1.14)\end{array}$ & $\begin{array}{c}0.0300 \\
(0.33)\end{array}$ & $\begin{array}{c}0.0294 \\
(0.32)\end{array}$ & $\begin{array}{c}0.0279 \\
(0.30)\end{array}$ \\
\hline Yearly \& Ind. Dummies & YES & YES & YES & YES & YES & YES & YES & YES & YES \\
\hline Adj. R-square & 0.2113 & 0.2207 & 0.2146 & 0.1050 & 0.1069 & 0.1049 & 0.0720 & 0.0712 & 0.0717 \\
\hline Num. of Obs. & 764 & 764 & 764 & 783 & 783 & 783 & 643 & 643 & 643 \\
\hline \multirow{2}{*}{ Variable } & \multicolumn{9}{|c|}{ Panel D. Matching Algorithm: Mahala } \\
\hline & \multicolumn{3}{|c|}{ ExecuPayT } & \multicolumn{3}{|c|}{ ExecuPayA } & \multicolumn{3}{|c|}{ ExecuPayR } \\
\hline ID_d & $\begin{array}{c}13421^{* * *} \\
(2.19)\end{array}$ & & & $\begin{array}{c}-390.22 \\
(-0.63)\end{array}$ & & & $\begin{array}{l}2.2307 \\
(0.72)\end{array}$ & & \\
\hline ID_num & & $\begin{array}{c}11201 * * * \\
(3.79)\end{array}$ & & & $\begin{array}{c}238.54 \\
(0.80)\end{array}$ & & & $\begin{array}{c}0.7676 \\
(0.51)\end{array}$ & \\
\hline ID_r & & & $\begin{array}{c}549.24 * * * \\
(2.78)\end{array}$ & & & $\begin{array}{c}0.0232 \\
(0.00)\end{array}$ & & & $\begin{array}{l}0.0590 \\
(0.59)\end{array}$ \\
\hline Lnasset & $\begin{array}{c}31581^{* * *} \\
(11.3)\end{array}$ & $\begin{array}{c}30933 * * * \\
(11.1)\end{array}$ & $\begin{array}{c}31500^{* * * *} \\
(11.3)\end{array}$ & $\begin{array}{c}3006.3^{* * *} * \\
\quad(10.5)\end{array}$ & $\begin{array}{c}2996.0^{* * *} \\
(10.5)\end{array}$ & $\begin{array}{c}3006.3^{* * *} \\
(10.5)\end{array}$ & $\begin{array}{c}-2.5828^{*} \\
(-1.76)\end{array}$ & $\begin{array}{c}-2.6002 * * * \\
(-1.77)\end{array}$ & $\begin{array}{c}-2.5671^{* * *} * \\
(-1.75)\end{array}$ \\
\hline Debt & $\begin{array}{c}-144.96^{* *} \\
(-2.34)\end{array}$ & $\begin{array}{c}-154.64 * * \\
(-2.51)\end{array}$ & $\begin{array}{c}-150.45^{* *} \\
(-2.43)\end{array}$ & $\begin{array}{c}-13.417 * * \\
(-2.13)\end{array}$ & $\begin{array}{c}-13.947 * * \\
(-2.21)\end{array}$ & $\begin{array}{c}-13.588 * * \\
(-2.16)\end{array}$ & $\begin{array}{c}-0.0240 \\
(-0.75)\end{array}$ & $\begin{array}{r}-0.0240 \\
(-0.75)\end{array}$ & $\begin{array}{r}-0.0243 \\
(-0.76)\end{array}$ \\
\hline CDdummy & $\begin{array}{l}2502.5 \\
(0.29)\end{array}$ & $\begin{array}{c}2074.0 \\
(0.24)\end{array}$ & $\begin{array}{c}2216.3 \\
(0.26)\end{array}$ & $\begin{array}{l}42.897 \\
(0.05)\end{array}$ & $\begin{array}{l}13.270 \\
(0.02)\end{array}$ & $\begin{array}{l}35.391 \\
(0.04)\end{array}$ & $\begin{array}{c}-26.060 * * * \\
(-5.73)\end{array}$ & $\begin{array}{c}-26.077 * * * \\
(-5.72)\end{array}$ & $\begin{array}{c}-26.095 * * * \\
(-5.73)\end{array}$ \\
\hline Profit & $\begin{array}{r}19.991 \\
(0.07)\end{array}$ & $\begin{array}{c}29.656 \\
(0.10)\end{array}$ & $\begin{array}{c}-1.0469 \\
(0.00)\end{array}$ & $\begin{array}{c}64.523 * \\
(1.85)\end{array}$ & $\begin{array}{c}66.874 * \\
(1.92)\end{array}$ & $\begin{array}{c}65.569 * \\
(1.89)\end{array}$ & $\begin{array}{c}-0.8121 \text { *** } \\
(-3.41)\end{array}$ & $\begin{array}{c}-0.8192 * * * \\
(-3.44)\end{array}$ & $\begin{array}{c}-0.8219 * * * \\
(-3.44)\end{array}$ \\
\hline MTB & $\begin{array}{c}9999.6^{* * *} \\
(2.63)\end{array}$ & $\begin{array}{c}10062 * * * \\
(2.66)\end{array}$ & $\begin{array}{c}9985.8^{* * * *} \\
(2.63)\end{array}$ & $\begin{array}{c}2016.9 * * * \\
\quad(4.57)\end{array}$ & $\begin{array}{c}1968.7 * * * \\
(4.47)\end{array}$ & $\begin{array}{c}1990.8^{* * *} \\
(4.51)\end{array}$ & $\begin{array}{c}-1.5140 \\
(-0.66)\end{array}$ & $\begin{array}{r}-1.4144 \\
(-0.62)\end{array}$ & $\begin{array}{r}-1.4531 \\
(-0.64)\end{array}$ \\
\hline StockRet & $\begin{array}{l}-6506.0 \\
(-1.39)\end{array}$ & $\begin{array}{l}-6583.1 \\
(-1.41)\end{array}$ & $\begin{array}{l}-6443.6 \\
(-1.38)\end{array}$ & $\begin{array}{l}-625.69 \\
(-1.36)\end{array}$ & $\begin{array}{l}-564.33 \\
(-1.23)\end{array}$ & $\begin{array}{l}-593.28 \\
(-1.30)\end{array}$ & $\begin{array}{c}0.2332 \\
(0.10)\end{array}$ & $\begin{array}{c}0.1475 \\
(0.06)\end{array}$ & $\begin{array}{l}0.1885 \\
(0.08)\end{array}$ \\
\hline Board & $\begin{array}{c}-2608.8 * \\
(-1.72)\end{array}$ & $\begin{array}{c}-3141.2^{* *} \\
(-2.08)\end{array}$ & $\begin{array}{l}-2107.0 \\
(-1.39)\end{array}$ & $\begin{array}{c}-35.806 \\
(-0.25)\end{array}$ & $\begin{array}{l}-46.646 \\
(-0.32)\end{array}$ & $\begin{array}{l}-36.726 \\
(-0.25)\end{array}$ & $\begin{array}{l}-0.4341 \\
(-0.62)\end{array}$ & $\begin{array}{c}-0.4586 \\
(-0.65)\end{array}$ & $\begin{array}{l}-0.3831 \\
(-0.54)\end{array}$ \\
\hline CEOhold & $\begin{array}{l}1740.0 \\
(1.13)\end{array}$ & $\begin{array}{l}1949.8 \\
(1.27)\end{array}$ & $\begin{array}{l}1827.0 \\
(1.19)\end{array}$ & $\begin{array}{r}-82.094 \\
(-0.52)\end{array}$ & $\begin{array}{r}-78.461 \\
(-0.49)\end{array}$ & $\begin{array}{r}-82.752 \\
(-0.52)\end{array}$ & $\begin{array}{c}0.9765 \\
(1.22)\end{array}$ & $\begin{array}{c}0.9998 \\
(1.25)\end{array}$ & $\begin{array}{c}0.9972 \\
(1.25)\end{array}$ \\
\hline Insthold & $\begin{array}{c}142.84 \\
(0.85)\end{array}$ & $\begin{array}{c}126.79 \\
(0.76)\end{array}$ & $\begin{array}{c}128.87 \\
(0.77)\end{array}$ & $\begin{array}{r}-11.981 \\
(-0.68)\end{array}$ & $\begin{array}{r}-11.575 \\
(-0.65)\end{array}$ & $\begin{array}{c}-11.519 \\
(-0.65)\end{array}$ & $\begin{array}{c}0.0952 \\
(1.07)\end{array}$ & $\begin{array}{c}0.0924 \\
(1.03)\end{array}$ & $\begin{array}{c}0.0926 \\
(1.04)\end{array}$ \\
\hline Yearly \& Ind. Dummies & YES & YES & YES & YES & YES & YES & YES & YES & YES \\
\hline Adj. R-square & 0.1903 & 0.2003 & 0.1934 & 0.2176 & 0.2179 & 0.2172 & 0.1026 & 0.1022 & 0.1023 \\
\hline Num. of Obs. & 772 & 772 & 772 & 784 & 784 & 784 & 644 & 644 & 644 \\
\hline
\end{tabular}

Note. This table reports the pooled OLS estimation results of the effect of board independence on executive compensation. Board independence is proxied by $I D \_d, I D \_n u m$ and $I D \_r$. Executive compensation is proxied by ExecuPayT, ExecuPayA and ExecuPayR. Panel A is estimation result under before-matching samples. Panel B, C and D report estimation result under after-matching samples through Nearest, Caliper and Mahala matching. Constant terms are omitted. The $t$-statistics are presented in parentheses. ${ }^{* * *},{ }^{* *}$ and ${ }^{*}$ denote estimated coefficient reaches statistical significance at the $1 \%, 5 \%$ and $10 \%$ levels, respectively.

The explanation is, while larger firm tends to have greater total pay and average pay to their executives (Note 12), as we matched treated firm by control firm with similar on size (Lnasset), the difference on size of treated firm and after-matching control firm is decreased. However, because treated firm tends to be larger, the average size of after-matching samples must be larger than the size of before matching samples. While executive of larger firm tends to have greater social reputation and higher management ability and firm with larger size tends to face greater coordination and internal control difficulty as well as systematic risk, higher executive pay of firm to compensate their effort to run a corporate with larger size and higher risk is common in practice. Even controlling size in after-matching sample, firm with greater degree of board independence (implies larger size) still pay more to their executive for running a big company.

Finally, we consider Heckman's two-stage estimation to correct for selection bias duo to selection on unobservables. Even though we have considered six observable factors affecting firm's introducing independent 
director, we still think that that some unobservable factors that contribute both to determining firm's introducing independent director and having effect on performance. Table 11 reports Heckman's two-stage estimation result of the effect of board independence on corporate performance and executive compensation. In Panel A, predicted variable is ExecuPayT. The first stage is a probability model determining firm's introducing independent director where the determinants are six observables used in PSM: Outside, Insthold, Inside, Profit, Lnasset and Debt. The second stage is the regression equation to evaluate the effect of board independence on executive compensation.

Estimated result of the first stage shows that firm with smaller Outside and Inside and greater Profit tends to introducing independent director and this result is consistent with estimation of propensity score function. The second stage show that firm's introducing independent director, greater number and ratio of independent director are significantly positive correlated with greater ExecuPayT. After correction selection bias duo to selection duo to unobservables, firm with greater degree of board independent tends to pay more to their executive. The reason behind firm with higher degree of board independence has higher total pay instead of higher average pay to executive is that, because firm with greater board independence tends to be larger firm whereas the size of the management is larger, total amount of compensation to all executives is larger though average amount per executive is not.

In Panel B, predicted variable is Profit. Estimation result of the first stage is generally consistent with the result in Panel A and propensity score function. Estimation result of the second stage shows that firm's independent director ratio is no longer significantly positive correlated with Profit. After correction selection bias duo to selection duo to unobservables, firm with greater degree of board independent have no more superior performance.

Totally, OLS regression result shows the degree of board independence positively associated with firm performance under before matching samples. It is interesting that after matched treated sample by control sample with similar observables through PSM, outsider block shareholding, institutional shareholding, insider shareholding, size, returns on equity and debt ratio, the evidence of significantly positive effect of introducing independent director and number of director on corporate performance is disappeared. OLS regression also shows that, before matching greater board independence is associated with higher total payment to executives and average payment per executive. Yet, after matching, the higher average pay is vanished. Based on Heckman's two-stage estimation, the evidence shows that firm with greater degree of board independence is no longer has significantly superior performance, yet higher total payment is still alive. The explanation is firm with higher degree board independence tends to be larger firm, larger firm implies the number of managers tends to larger, that's why the total amount of payment to all executives is high but not average payment per executive.

Existing studies on examining the linkage among independent director, executive compensation and corporate performance are well documented. While the conclusion is ambiguous, they lacked controlled sample selection bias duo to samples non-random assigned to firm with more independent board versus less. In this paper, we found that several factors systematically affect firm's introducing independent board on their board. After matching firm with independent board by firm without independent board with similar characteristic, greater degree of board independence, level of executive compensation and corporate performance are not statistically significant. Based on our analysis, better exerting of managerial monitoring and advising function by independent director is quite limited, yet overpay on executive compensation is not also found by our analysis. The implication of this study is that applying conventional wisdom and conclusion of existing studies based on before matching samples should be careful. Any policy impact evaluation by non-experimental data should consider "ceteris paribus" or "other things being equal" before regression. The greater degree of similarity of variables other than policy instrument variable, the regression correlation are more approaching to causal effect. 
Table 12. The effect of board independence on corporate performance and executive compensation-heckman's two-stage estimation

\begin{tabular}{|c|c|c|c|c|c|c|c|c|c|c|}
\hline \multicolumn{5}{|c|}{ Panel A. Predicted Variable: ExecuPayT } & \multicolumn{6}{|c|}{ Panel B. Predicted Variable: Profit } \\
\hline \multirow{2}{*}{\multicolumn{2}{|c|}{$\frac{\text { First Stage }}{\text { Variable }}$}} & & \multicolumn{2}{|c|}{ Second Stage } & \multirow{2}{*}{$\begin{array}{l}\text { First Stage } \\
\text { Variable }\end{array}$} & \multicolumn{5}{|c|}{ Second Stage } \\
\hline & & & & & & & Model 1 & Model 2 & Model 3 & Model 4 \\
\hline ID_d & & $\begin{array}{l}160511^{* * *} \\
(5.40)\end{array}$ & & & & & & & & \\
\hline ID_num & & & $\begin{array}{l}28303^{* * *} \\
(12.3)\end{array}$ & & $I D \_r$ & & $\begin{array}{l}0.0682 \\
(0.37)\end{array}$ & $\begin{array}{l}0.0598 \\
(0.28)\end{array}$ & $\begin{array}{l}0.0495 \\
(0.26)\end{array}$ & $\begin{array}{l}0.0555 \\
(0.28)\end{array}$ \\
\hline$I D \_r$ & & & & $\begin{array}{l}773.01^{* * *} \\
(5.12)\end{array}$ & Outside & $\begin{array}{l}-0.0027 \\
(-1.13)\end{array}$ & & & & \\
\hline Outside & $\begin{array}{l}-0.0117^{* * *} \\
(-3.79)\end{array}$ & & & & Inside & $\begin{array}{l}-0.0056^{* * *} \\
(-2.63)\end{array}$ & & & & \\
\hline Inside & $\begin{array}{l}-0.0119^{* * *} \\
(-4.21)\end{array}$ & & & & Profit & $\begin{array}{l}0.0093^{* * *} \\
(5.71)\end{array}$ & & & & \\
\hline Profit & $\begin{array}{l}0.0082^{* * *} \\
(4.01)\end{array}$ & $\begin{array}{l}-115.93 \\
(-1.29)\end{array}$ & $\begin{array}{l}-117.98 \\
(-1.31)\end{array}$ & $\begin{array}{l}-124.00 \\
(-1.37)\end{array}$ & Lnasset & $\begin{array}{l}-0.0208 \\
(-0.87)\end{array}$ & $\begin{array}{l}2.4700^{*} \\
(1.86)\end{array}$ & & $\begin{array}{l}1.2803 \\
(0.85)\end{array}$ & $\begin{array}{l}1.2853 \\
(0.82)\end{array}$ \\
\hline Lnasset & $\begin{array}{l}0.0091 \\
(0.29)\end{array}$ & $\begin{array}{l}14628^{* * *} \\
(11.2)\end{array}$ & $\begin{array}{l}14028^{* * *} \\
(10.7)\end{array}$ & $\begin{array}{l}14619^{* * *} \\
(11.1)\end{array}$ & Debt & $\begin{array}{l}-0.0007^{* *} \\
(-2.09)\end{array}$ & $\begin{array}{l}-0.0139^{* *} \\
(-2.47)\end{array}$ & & $\begin{array}{l}-0.0130^{* *} \\
(-2.21)\end{array}$ & $\begin{array}{l}-0.0173^{* * *} \\
(-2.65)\end{array}$ \\
\hline Debt & $\begin{array}{l}-0.0005 \\
(-1.31)\end{array}$ & $\begin{array}{l}-10.027^{*} \\
(-1.83)\end{array}$ & $\begin{array}{l}-10.412^{*} \\
(-1.88)\end{array}$ & $\begin{array}{l}-10.100^{*} \\
(-1.82)\end{array}$ & $\boldsymbol{R d}$ & & $\begin{array}{l}-0.7443^{* *} \\
(-2.18)\end{array}$ & & $\begin{array}{l}-0.6311^{*} \\
(-1.77)\end{array}$ & $\begin{array}{l}-0.5928 \\
(-1.58)\end{array}$ \\
\hline CDdummy & & $\begin{array}{l}-1131.6 \\
(-0.43)\end{array}$ & $\begin{array}{l}-1116.6 \\
(-0.42)\end{array}$ & $\begin{array}{l}-1327.5 \\
(-0.50)\end{array}$ & Salesgrowth & & $\begin{array}{l}0.0001 \\
(0.13)\end{array}$ & & $\begin{array}{l}0.0002 \\
(0.16)\end{array}$ & $\begin{array}{l}0.0002 \\
(0.14)\end{array}$ \\
\hline MTB & & $\begin{array}{l}7053.2^{* * * *} \\
(6.06)\end{array}$ & $\begin{array}{l}7180.8^{* * *} \\
(6.12)\end{array}$ & $\begin{array}{l}6986.8^{* * *} \\
(5.94)\end{array}$ & Age & & $\begin{array}{l}-0.0662 \\
(-0.58)\end{array}$ & & $\begin{array}{l}-0.0192 \\
(-0.15)\end{array}$ & $\begin{array}{l}-0.0575 \\
(-0.39)\end{array}$ \\
\hline StockRet & & $\begin{array}{l}-1881.3 \\
(-1.26)\end{array}$ & $\begin{array}{l}-2192.2 \\
(-1.46)\end{array}$ & $\begin{array}{l}-1866.3 \\
(-1.24)\end{array}$ & Board & & & $\begin{array}{l}0.1287 \\
(0.24)\end{array}$ & $\begin{array}{l}-0.0418 \\
(-0.08)\end{array}$ & $\begin{array}{l}-0.0831 \\
(-0.16)\end{array}$ \\
\hline Baord & & $\begin{array}{l}-1199.7^{* * *} \\
(-2.83)\end{array}$ & $\begin{array}{l}-1425.8^{* * *} \\
(-3.33)\end{array}$ & $\begin{array}{l}-1059.6^{* *} \\
(-2.46)\end{array}$ & CEOhold & & & $\begin{array}{l}0.7433 \\
(1.09)\end{array}$ & $\begin{array}{l}0.7551 \\
(1.18)\end{array}$ & $\begin{array}{l}0.8080 \\
(1.26)\end{array}$ \\
\hline CEOhold & & $\begin{array}{l}2077.6^{* * *} \\
(3.97)\end{array}$ & $\begin{array}{l}2207.9^{* * * *} \\
(4.19)\end{array}$ & $\begin{array}{l}2134.9^{* * *} \\
(4.04)\end{array}$ & Pledge & & & $\begin{array}{l}-0.0435 \\
(-0.66)\end{array}$ & $\begin{array}{l}-0.0495 \\
(-0.81)\end{array}$ & $\begin{array}{l}-0.0502 \\
(-0.82)\end{array}$ \\
\hline Insthold & $\begin{array}{l}0.0008 \\
(0.43)\end{array}$ & $\begin{array}{l}180.73^{* *} \\
(2.48)\end{array}$ & $\begin{array}{l}172.29^{* *} \\
(2.35)\end{array}$ & $\begin{array}{l}177.90^{* *} \\
(2.42)\end{array}$ & Insthold & $\begin{array}{l}-0.0006 \\
(-0.40)\end{array}$ & & $\begin{array}{l}0.2589^{* * * *} \\
(3.09)\end{array}$ & $\begin{array}{l}0.2221^{* * *} \\
(2.74)\end{array}$ & $\begin{array}{l}0.2104^{* *} \\
(2.52)\end{array}$ \\
\hline Yearly & & & & & Yearly & & & & & \\
\hline $\begin{array}{l}\text { \& Ind. } \\
\text { Dummies }\end{array}$ & & YES & $Y E S$ & $Y E S$ & $\begin{array}{l}\text { \& Ind. } \\
\text { Dummies }\end{array}$ & & $N O$ & NO & NO & YES \\
\hline Chi-square & & 376.23 & 509.65 & 398.68 & Chi-square & & 103.08 & 78.38 & 105.78 & 111.69 \\
\hline \# of Obs. & & 2.943 & 2.943 & 2.943 & \# of Obs. & & 4,710 & 4,714 & 4,710 & 4,710 \\
\hline
\end{tabular}

Note. This table reports Heckman's two-stage estimation result of the effect of board independence on corporate performance and executive compensation. In Panel A, predicted variable is ExecuPayT, and in Panel B, predicted variable is Profit. Constant terms are omitted. The $z$-statistics are presented in parentheses. ${ }^{* * *},{ }^{* *}$ and ${ }^{*}$ denote estimated coefficient reaches statistical significance at the $1 \%, 5 \%$ and $10 \%$ levels, respectively.

\section{Conclusion}

While convention wisdom advocates that increasing independent director representation on board enhances managerial monitoring and advising and thus board efficiency is increased. Academically, hundreds of existing studies investigated whether board independence indeed increases corporate performance and limit overpay of executive compensation. However, sample selection duo to observables and unobservables causes sample selection bias and constitutes endogeneity problem. Rare extant studies on this issue deal with for this problem and estimated coefficients on board independence are likely to be biased. Based on listed companies on TWSE, we address the issue of selection bias and mitigated it PSM and Heckman's two stage estimation.

Our basic findings are twofold. First, outperformance of firm with board independence under before-matching samples vanished as after-matching samples are used. Second, higher average amount of executive compensation of firm with board independence under before-matching samples also disappeared, yet higher total pay to all executives are still exist. Because higher total pay is explained by larger management's demand for more 
executives of larger firm, the overall evidence generally postulates that board independence is not correlated with better corporate performance and executive compensation inflation.

The managerial implication of this paper consists of two fold. First, while the validity and effectiveness of introducing independent director does not supported by the evidence, the benefits of introducing independent director cannot be overstated by the regulator. There is an old saying that when God has his church, the devil will have his chapel. Independent director is appointed by board of director. From demand side, a board has tendency of appointing an independent director that is easy to work with. From the supply side, an independent director may concern his/her career and compensation and act as an obedient board member. Under these two conditions, the function of monitoring versus advising to improve the quality of managerial decision by independent director is substantially weakened. Second, the worldwide pursuit of the fashion of introducing independent director cause shortage of high quality independent director. Some companies may appoint an average-quality as their independent directors to follow government regulation, fit corporate governance practices and show off their board independence on financial market. Yet, the ability, experience and professionals are too ordinary to contribute on improving managerial decision quality and corporate performance and profitability.

Our research limitation and possible extensions proceeds as following. First, in applying PSM, researchers should take care of that statistical inference is restricted to samples of treated firms and after-matching control firms. In other words, statistical inference from PSM is limited on the range of propensity scores of common support. Our empirical findings based on after-matching samples can only generalize to samples share similar characteristics with after-matching samples rather than the whole population. One treat-one control could extend to one treat-multiple control samples. Second, in sample matching, equivalent in means of observables is a check for matching effectiveness. Other checks such as equivalent in propensity score between two groups of firms or F-test on simultaneously equivalent for all observables could be checked. Third, independent director may exert different effect depending on which committee they are assigned to (e.g. nominating, compensation and audit committee). While the data on listed firms on TWSE is limited now, and future studies could check the direct effect of introduction of independent director to different committee on corporate performance and executive compensation. Assigned independent director to audit committee may positively moderates board independence-performance linkage. Assigned independent director to compensation committee may positively moderates pay-performance sensitivity of executive compensation. Fourth, Free rider problem may exist as the number of independent director increases. The busyness of independent director may have positive (external resources and reputation) versus negative (less commitment) effect on exerting their monitoring and advising function. Thus, future study could examine nonlinear effect of board independence and moderated effect of busyness on board independence-economic outcome linkage.

\section{Acknowledgments}

The authors would like to thank the anonymous reviewers for helpful and constructive comments that contributed to improving the final version of the paper. All remaining errors are my own.

\section{References}

Adams, R., \& Ferreira, D. (2007). A Theory of Friendly Board. Journal of Finance, 62, 217-250. http://dx.doi.org/10.1111/j.1540-6261.2007.01206.x

Adams, R., \& Ferreira, D. (2007). Do Directors Perform for Pay? Journal of Accounting and Economics, 46, 154-171. http://dx.doi.org/10.1016/j.jacceco.2008.06.002

Agrawal, A., \& Mandelker, G. (1990). Large Shareholders and the Monitoring of Managers: The Case of Antitakeover Charter Amendments. Journal of Financial and Quantitative Analysis, 25, 143-161. http://dx.doi.org/10.2307/2330821

Bhagat, S., \& Black, B. (2002). The Non-Correlation between Board Independence and Long-term Firm Performance. Journal of Corporation Law, 27, 231-273. http://dx.doi.org/10.2139/ssrn.133808

Brickley, J., Coles, J., \& Terry, R. (1994). Outside Directors and the Adoption of Poison Pills. Journal of Financial Economics, 35, 371-90. http://dx.doi.org/10.1016/0304-405X(94)90038-8

Cagwin, D., \& Bouwman, M. J. (2002). The Association between Activity-Based Costing and Improvement in Financial Performance. Management Accounting Research, 13, 1-39. http://dx.doi.org/10.1006/mare.2001.0175

Chen, C. W., Lin, B., \& Yi, B. (2013). Directors' and Officers' Liability Insurance and Managerial Compensation. 
Journal of International Finance Studies, 13, 29-42. http://dx.doi.org/10.18374/JIFS-13-1.3

Chen, I. L., \& Lin, W. I. (2013). The Decision of Having Independent Members on the Board and its Relation to Performance. Management and System, 20, 695-723.

Chen, J. P., \& Jaggi, B. (2000). Association between Independent Non-executive Directors, Family Control and Financial Disclosures in Hong Kong. Journal of Accounting and Public Policy, 19, 285-310. http://dx.doi.org/10.1016/S0278-4254(00)00015-6

Chhaochharia, V., \& Grinstein, Y. (2009). CEO Compensation and Board Structure. Journal of Finance, 64, 231-261. http://dx.doi.org/10.2139/ssrn.901642

Claessens, S., Djankov, S., \& Lang, P. (n. d.). The Separation of Ownership and Control in East Asian Corporations. Journal of Financial Economics, 58, 81-112. Retrieved from http://ssrn.com/abstract=206448

Core, E., Holthausen, R., \& Larcker, D. (1999). Corporate Governance, Chief Executive Officer Compensation, and Firm Performance. Journal of Financial Economics, 51, 371-406. http://dx.doi.org/10.1108/14720700810863779

Cotter, F., Anil, S., \& Zenner, M. (1997). Do Independent Directors Enhance Target Shareholder Wealth during Tender Offers? Journal of Financial Economics, $195-218$. http://dx.doi.org/10.1016/S0304-405X(96)00886-0

Cram, D. P., Karan, V., \& Stuart, I. (2009). Three Threats to Validity of Choice-Based and Matched-Sample Studies in Accounting Research. Contemporary Accounting Research, 26, 477-516. http://dx.doi.org/10.1506/car.26.2.7

Dehejia, R. H., \& Wahba, S. (2002). Propensity Score Matching Methods for Nonexperimental Causal Studies. The Review of Economics and Statistics, 84, 151-161. http://dx.doi.org/10.1162/003465302317331982

Demsetz, H., \& Villalonga, B. (2001). Ownership Structure and Corporate Performance. Journal of Corporate Finance, 7, 209-233. http://dx.doi.org/10.1016/S0929-1199(01)00020-7

Duchin, R., Matsusaka, J., \& Ozbas, O. (2010). When are Outside Directors Effective? Journal of Financial Economics, 96, 195-214. http://dx.doi.org/10.1016/j.jfineco.2009.12.004

Elliot, R. K., \& Jacobson, P. D. (1994). Cost and Benefits of Business Information Disclosure. Accounting Horizons, 8, 80-96. http://dx.doi.org/10.2139/ssrn.316145

Fama, E. F. (1980). Agency Problems and the Theory of the Firm. Journal of Political Economy, 88, $288-307$. http://dx.doi.org/10.1086/260866

Fama, E. F., \& Jensen, M. C. (1983). Separation of Ownership and Control. The Journal of Law and Economics, 26, 301-325. http://dx.doi.org/10.1086/467037

Fich, M., \& Anil, S. (2006). Are Busy Boards Effective Monitors? Journal of Finance, 61, 689-724. http://dx.doi.org/10.1111/j.1540-6261.2006.00852.x

Forker, J. J. (1992). Corporate Governance and Disclosure Quality. Accounting and Business Research, 22, 111-124. http://dx.doi.org/10.1080/00014788.1992.9729426

Fuzi, S., \& Julizaerma, M. K. (2016). Board Independence and Firm Performance. Procedia Economics and Finance, 37, 460-465. http://dx.doi.org/10.1016/S2212-5671(16)30152-6

Gordon, L., \& Pound, J. (1993). Information, Ownership Structure, and Shareholder Voting: Evidence from Shareholder-Sponsored Corporate Governance Proposal. Journal of Finance, 48, 697-718. http://dx.doi.org/10.1111/j.1540-6261.1993.tb04734.x

Guthrie, K., Sokolowsky, J., \& Wan, K. M. (2012). CEO Compensation and Board Structure Revisited. Journal of Finance, 67, 1149-1168. http://dx.doi.org/10.1111/j.1540-6261.2012.01744.x

Harris, M., \& Raviv, A. (2008). A Theory of Board Control and Size. Review of Financial Studies, 21, $1797-1832$. http://dx.doi.org/10.1093/rfs/hhl030

Heckman, J. (1979). Sample Selection Bias as a Specification Error. Econometrica, 47, $153-162$. http://dx.doi.org/10.2307/1912352

Hermalin, B., \& Weisbach, M. (2003). Boards of Directors as an Endogenously Determined Institution: A Survey of the Economic Literature. FRBNY Economic Policy Review, 7-26.

Hermalin, E., \& Weisbach, M. (1988). The Determinants of Board Composition. The RAND Journal of 
Economics, 19, 589-606. http://dx.doi.org/10.1108/18325910710732867

Hermalin, E., \& Weisbach, M. (1991). The Effects of Board Composition and Direct Incentives on Firm Performance. Financial Management, 20, 101-112. http://dx.doi.org/10.2307/3665716

Hermalin, E., \& Weisbach, M. (1998). Endogenously Chosen Boards of Directors and Their Monitoring of the CEO. American Economic Review, 88, 96-118.

Ittner, C. D., Lanen, W. N., \& Larcker, D. F. (2002). The Association between Activity-Based Costing and Manufacturing Performance. Journal of Accounting Research, 40, 711-726. http://dx.doi.org/10.1111/1475-679X.00068

Jensen, M. (1993). The Modern Industrial Revolution, Exit, and the Failure of Internal Control Systems. Journal of Finance, 48, 831-880. http://dx.doi.org/10.1111/j.1540-6261.1993.tb04022.x

Jensen, M. C., \& Ruback, R. S. (1983). Market for Corporate Control: Empirical Evidence. Journal of Financial Economics, 1, 5-50. http://dx.doi.org/10.1016/0304-405X(83)90004-1

Jensen, M., \& Meckling, W. (1976). Theory of the Firm: Managerial Behavior, Agency Costs and Ownership Structure. Journal of Financial Economics, 3, 305-360. http://dx.doi.org/10.2139/ssrn.94043

Jones, D. C., \& Kato, T. (1995). The Productivity Effects of Employee Stock Ownership Plans and Bonuses: Evidence from Japanese Panel Data. American Economic Review, 85, 391-414.

Klein, A. (1998). Firm Performance and Board Committee Structure. Journal of Law \& Economics, 41, 275-303. http://dx.doi.org/10.1086/467391

Leland, H. E., \& Pyle, D. H. (1977). Informational Asymmetries, Financial Structure, and Financial Intermediation. Journal of Finance, 32, 371-387. http://dx.doi.org/10.2307/2326770

Leung, S., Richardson, G., \& Jaggi, B. (2014). Corporate board and board committee independence, firm performance, and family ownership concentration: An analysis based on Hong Kong firms. Journal of Contemporary Accounting \& Economics, 10, 16-31. http://dx.doi.org/10.1016/j.jcae.2013.11.002

Loughran, T., \& Ritter, J. R. (1997). The Operating Performance of Firms Conducting Seasoned Equity Offerings. Journal of Finance, 52, 1823-1850. http://dx.doi.org/10.1111/j.1540-6261.1997.tb02743.x

Masulis, R. W., \& Mobbs, S. (2012). Are All Inside Directors the Same? Do they Entrench CEOs or Enhance Board Decision Making? Journal of Finance, forthcoming. http://dx.doi.org/10.2139/ssrn.1108036

McConnell, J., \& Servaes, H. (1990). Additional Evidence on Equity Ownership and Corporate Value. Journal of Financial Economics, 27, 595-612. http://dx.doi.org/10.1016/0304-405X(90)90069-C

Morck, R., Shleifer, A., \& Vishny, R. W. (1988). Management Ownership and Market Valuation: An Empirical Analysis. Journal of Financial Economics, 20, 293-315. http://dx.doi.org/10.1016/0304-405X(88)90048-7

O’Reilly, V. M., McDonnell, P. J., Winograd, B. N., Gerson, J. S., \& Jaenicke, H. R. (1998). Montgomery's Auditing (12th ed.). New York, NY: John Wiley \& Sons.

Oviatt, B. M. (1988). Agency and Transaction Cost Perspectives on the Manager-Shareholder Relationship, Incentives for Congruent Interests. Academy of Management Review, 13, 214-225.

Peasnell, K. V., Pope, P. F., \& Young, S. (2005). Board Monitoring and Earnings Management: Do Outside Directors Influence Abnormal Accruals? Journal of Business Finance and Accounting, 32, 1311-1345. http://dx.doi.org/10.2139/ssrn.249557

Pound, J. (1988). Proxy Contests and the Efficiency of Shareholder Oversight. Journal of Financial Economics, 20, 237-264. http://dx.doi.org/10.1016/0304-405X(88)90046-3

Raheja, C. (2005). Determinant of Board Size and Composition: A Theory of Corporate Boards. Journal of Financial and Quantitative Analysis, 40, 283-206. http://dx.doi.org/10.2139/ssrn.522542

Riasi, A. (2015). Competitive Advantages of Shadow Banking Industry: An Analysis Using Porter Diamond Model. Business Management and Strategy, 6, 15-27. http://dx.doi.org/10.5296/bms.v6i2.8334

Rosenbaum, P., \& Rubin, D. (1983). The Central Role of the Propensity Score in Observational Studies for Causal Effects. Biometrika, 70, 41-55. http://dx.doi.org/10.1093/biomet/70.1.41

Rosenbaum, P., \& Rubin, D. (1985a). Constructing a Control Group Using Multivariate Matched Sampling Methods that Incorporate the Propensity. American Statistician, 39, 33-38.

Rosenbaum, P., \& Rubin, D. (1985b). The Bias Due to Incomplete Matching. Biometrics, 41, 103-116. 
http://dx.doi.org/10.1017/CBO9780511810725.020

Rosenstein, S., \& Wyatt, J. G. (1990). Outside Directors, Board Independence, and Shareholder Wealth. Journal of Financial Economics, 26, 175-191. http://dx.doi.org/10.1016/0304-405X(90)90002-H

Rubin, D. (1973). Matching to Remove Bias in Observational Studies. Biometrics, 29, $159-183$. http://dx.doi.org/10.1017/CBO9780511810725.007

Rubin, D. (1977). Assignment to a Treatment Group on the Basis of a Covariate. Journal of Educational Statistics, 2, 1-26. http://dx.doi.org/10.2307/1164933

Rubin, D. B., \& Thomas, N. (1992). Characterizing the Effect of Matching Using Linear Propensity Score Methods with Normal Distributions. Biometrika, 79, 797-809. http://dx.doi.org/10.1093/biomet/79.4.797

Sengupta, P. (1998). Corporate Disclosure Quality and the Cost of Debt. The Accounting Review, 73, 459-474.

Shen, C. H., \& Chang, Y. (2009). Ambition versus Conscience, does Corporate Social Responsibility Pay off? The Application of Matching Methods. Journal of Business Ethics, 88, 133-153. http://dx.doi.org/10.1007/s10551-008-9826-9

Stulz, R. (1988). Managerial Control of Voting Rights, Financing Policies and the Market for Corporate Control. Journal of Financial Economics, 20, 25-54. http://dx.doi.org/10.1016/0304-405X(88)90039-6

Su, C. C. (2010). Empirical Study on the Implementation of Independent Director System in Taiwan. Master Thesis, National Chiao-Tung University, Taiwan.

Tucker, J. W. (2007). Is Openness Penalized? Stock Returns around Earnings Warnings. The Accounting Review, 82, 1055-1087. http://dx.doi.org/10.2139/ssrn.744706

Tucker, J. W. (2011). Selection Bias and Econometric Remedies in Accounting and Finance Research. Journal of Accounting Literature, forthcoming.

Wang, W. (2014). Independent Directors and Corporate Performance in China: A Meta-Empirical Study. Working paper, University of Auckland. http://dx.doi.org/10.2139/ssrn.2417078

Watts, R. L., \& Zimmerman, J. L. (1986). Positive Accounting Theory. Englewood Cliffs, N. J.: Prentice-Hall.

Weisbach, M. S. (1988). Outside Directors and CEO Turnover. Journal of Financial Economics, 20, 431-460. http://dx.doi.org/10.1016/0304-405X(88)90053-0

Wintoki, M. B. (2007). Corporate Boards and Regulation: The Effect of the Sarbanes - Oxley Act and the Exchange Listing Requirements on Firm Value. Journal of Corporate Finance, 13, 229-250. http://dx.doi.org/10.1016/j.jcorpfin.2007.03.001

Wooldridge, J. M. (2002). Econometric Analysis of Cross Section and Panel Data. The MIT Press.

Yermack, D. (1996). Higher Market Valuation of Companies with a Small Board of Directors. Journal of Financial Economics, 40, 185-211. http://dx.doi.org/10.1016/0304-405X(95)00844-5

Zhao, Z. (2004). Using Matching to Estimate Treatment Effects: Data Requirement, Matching Metrics, and Monte Carlo Evidence. Review of Economics and Statistics, 86, 91-107. http://dx.doi.org/10.1162/003465304323023705

\section{Notes}

Note 1. For example, independent director of TSMC includes world-class entrepreneurs or scholars, such as Lobbezoo, (CFO of Philips Semiconductors), Michael Porter (professor of Harvard University), Bangfei Jazz (the former British Telecom CEO) and David Thoreau (Professor of MIT).

Note 2. A To avoid the estimation bias due to the endogeneity of firm's introducing independent director, Duchin, Matsusaka and Ozbas (2010) examined the relationship between board independence and firm performance during U.S. regulatory change between 1999 and 2002. Chhaochharia and Grinstein (2009) and Guthrie, Sokolowsky and Wan (2012) examined the effect of board independence on CEO compensation under the background of new NYSE and Nasdaq listing rule following the passage of SOX in 2002.

Note 3. Bhagat and Black (2002) and Hermalin and Weisbach (2003) indicated that without controlling the endogeneity of key independent variable, estimation and explanation for coefficient are likely to be biased.

Note 4. Examples of observable differences are firm size and growth. Examples of unobservables are information revealed during a financial event that are known to some market participants or other information 
that is publically disclosed by the company but is too costly for researchers to collect (Tucker, 2011).

Note 5. Tucker (2011) mentioned that matched-sample designs have a long history in accounting and finance research (Cram, Karan, \& Stuart, 2009; Loughran \& Ritter, 1997).

Note 6. Correction for selection bias duo to selection on unobservables follows Heckman (1979)'s two stage estimation.

Note 7. Rubin and Thomas ${ }_{\lambda}(1992)$ demonstrated that using estimated probability of being treated based on observable characteristics $X, \hat{P}(X)$, instead of $P(X)$, reduces selection bias.

Note 8. According Shen and Chang (2009), $\eta$ is specified as quarter of standard error of all estimated propensity scores.

Note 9. Bhagat and Black (2002) found that firm with higher tendency of setting independent director when their performance is bad in previous periods.

Note 10. One except is Outside.

Note 11. In model (1), main predictor is $I D \_d$, and five firm characteristic variables, Lnasset, Debt, Rd, Salesgrowth and Age are incorporated. In Model (2) main predictor is $I D \_d$, and four board and ownership structure variables, Board, CEOhold, Pledge and Insthold are incorporated. In mode (3), in addition to main predictor, five firm characteristic variables and four board and ownership structure variables are regressors. In model (4), in addition to all variables in model (3), ten year dummies and 17 industry dummies are added to control for macroeconomic and industry effect on corporate performance.

Note 12. In Table 3, the correlation coefficient between Lnasset and ExecuPayT is significantly positive (0.3598), the correlation coefficient between Lnasset and ExecuPayA is also significantly positive (0.3468).

Note 13. In model (1), main predictor is $I D \_d$, and five firm characteristic variables, Lnasset, Debt, $R d$, Salesgrowth and Age are incorporated. In Model (2) main predictor is $I D \_d$, and four board and ownership structure variables, Board, CEOhold, Pledge and Insthold are incorporated. In mode (3), in addition to main predictor, five firm characteristic variables and four board and ownership structure variables are regressors. In model (4), in addition to all variables in model (3), ten year dummies and 17 industry dummies are added to control for macroeconomic and industry effect on corporate performance.

\section{Copyrights}

Copyright for this article is retained by the author(s), with first publication rights granted to the journal.

This is an open-access article distributed under the terms and conditions of the Creative Commons Attribution license (http://creativecommons.org/licenses/by/3.0/). 